\title{
Exploring the potential linkages between oil-field brine reinjection, crystalline basement permeability, and triggered seismicity for the Dagger Draw Oil field, southeastern New Mexico, USA, using hydrologic modeling
}

\author{
Y. ZHANG ${ }^{1}$, S. S. EDEL ${ }^{1}, J \cdot$ PEPIN $^{1}, M \cdot P E R S O N^{1}, R \cdot B R O A D H E A D^{2}, J \cdot P \cdot$ ORTIZ $^{1}$, \\ S. L. BILEK ${ }^{1}$, P. MOZLEY ${ }^{1}$ AND J. P. EVANS ${ }^{3}$ \\ ${ }^{1}$ New Mexico Tech, Socorro, NM, USA; ${ }^{2}$ New Mexico Bureau of Geology \& Mineral Resources, Socorro, NM, USA; ${ }^{3}$ Utah \\ State University, Socorro, NM, USA
}

\begin{abstract}
We used hydrologic models to explore the potential linkages between oil-field brine reinjection and increases in earthquake frequency (up to $M_{d}$ 3.26) in southeastern New Mexico and to assess different injection management scenarios aimed at reducing the risk of triggered seismicity. Our analysis focuses on saline water reinjection into the basal Ellenburger Group beneath the Dagger Draw Oil field, Permian Basin. Increased seismic frequency $\left(>M_{d}\right.$ 2) began in 2001, 5 years after peak injection, at an average depth of $11 \mathrm{~km}$ within the basement $15 \mathrm{~km}$ to the west of the reinjection wells. We considered several scenarios including assigning an effective or bulk permeability value to the crystalline basement, including a conductive fault zone surrounded by tighter crystalline basement rocks, and allowing permeability to decay with depth. We initially adopted a $7 \mathrm{~m}(0.07 \mathrm{MPa})$ head increase as the threshold for triggered seismicity. Only two scenarios produced excess heads of $7 \mathrm{~m}$ five years after peak injection. In the first, a hydraulic diffusivity of $0.1 \mathrm{~m}^{2} \mathrm{~s}^{-1}$ was assigned to the crystalline basement. In the second, a hydraulic diffusivity of $0.3 \mathrm{~m}^{2} \mathrm{~s}^{-1}$ was assigned to a conductive fault zone. If we had considered a wider range of threshold excess heads to be between 1 and $60 \mathrm{~m}$, then the range of acceptable hydraulic diffusivities would have increased (between $0.1-0.01 \mathrm{~m}^{2} \mathrm{~s}^{-1}$ and $1-0.1 \mathrm{~m}^{2} \mathrm{~s}^{-1}$ for the bulk and fault zone scenarios, respectively). A permeability-depth decay model would have also satisfied the 5-year time lag criterion. We also tested several injection management scenarios including redistributing injection volumes between various wells and lowering the total volume of injected fluids. Scenarios that reduced computed excess heads by over $50 \%$ within the crystalline basement resulted from reducing the total volume of reinjected fluids by a factor of 2 or more.
\end{abstract}

Key words: Dagger Draw Oil field, hydrologic modeling, induced seismicity, Permian basin

Received 26 January 2016; accepted 23 August 2016

Corresponding author: Mark Person, Department of Earth \& Environmental Sciences, New Mexico Tech, Hydrology Program, 801 Leroy Place, Socorro, NM 87801-4796, USA.

Email: mperson@nmt.edu. Tel: +575 835 6506. Fax: +575 8356436.

Geofluids (2016) 16, 971-987

\section{INTRODUCTION}

Zhang et al. (2013) proposed that injection of oil-field brines into basal sedimentary rock reservoirs represents a key geologic factor related to triggered seismicity within the underlying crystalline basement. Fluid injection into a permeable, horizontally extensive reservoir allows for the rapid radial propagation of elevated fluid pressures outward from injection wells. In the absence of a basal confining unit, basal reservoir injection maximizes the amount of crystalline basement surface area exposed to elevated fluid pressures. If elevated fluid pressures within a basal reservoir encounter a relatively high-permeability fault (e.g., $10^{-14} \mathrm{~m}^{2}$ ) or if the bulk permeability of the crystalline basement is moderately high $\left(10^{-15}\right.$ to $\left.10^{-16} \mathrm{~m}^{2}\right)$, then fluid pressures can propagate downward over a period of a few years and laterally away from the injection site. If elevated fluid pressures come into contact with a critically stressed fault, only a small pressure increase is needed to trigger seismicity (Barton et al. 1995; Townend \& Zoback 2000).

Large, damaging, triggered earthquakes typically occur at depths of 4-6 km within the crystalline basement and 
up to $10-15 \mathrm{~km}$ away from the injection site (e.g., Keranen et al. 2013, 2014; Walsh \& Zoback 2015). The association between basal reservoir injection and induced seismicity within the underlying crystalline basement has been documented at a number of sites in Oklahoma and Arkansas (Table 1; Fig. 1; Keranen et al. 2013, 2014; Horton 2012). There are also a number of instances of induced seismicity where injection occurred directly into the crystalline basement, such as in Ohio and Colorado (Fig. 1; Table 1, Hsieh \& Bredehoeft 1981; Kim 2012).

Prior studies have reported a wide range of fluid pressure increases thought to be associated with triggered seismicity (Table 1). Hsieh \& Bredehoeft (1981) found that the pressure threshold associated with triggered seismicity at the Rocky Mountain Arsenal near Denver was $320 \mathrm{~m}$ (3.2 MPa) at an average depth of about $5 \mathrm{~km}$ within the crystalline basement. Keranen et al. (2014) concluded that a pore pressure increase of $0.07 \mathrm{MPa}$ was consistent with triggered seismicity in Oklahoma. Ge et al. (2009) estimated that filling of the Zipingpu dam with $200 \mathrm{~m}$ head of water $(2 \mathrm{MPa})$ resulted in a relatively small head change of $2.5-5 \mathrm{~m}(0.025-0.05 \mathrm{MPa})$ at depths of $10-20 \mathrm{~km}$ below the land surface near the Wenchuan earthquake foci. Saar \& Manga (2003) concluded that even smaller head changes (about $1 \mathrm{~m}$ or $0.01 \mathrm{MPa}$ ) were required to explain hydraulically induced earthquake swarms $4.5 \mathrm{~km}$ below Mt. Hood. Although oil-field operators are required to report injection pressures at the wellhead, this does not provide much insight into pore pressures deep within the crystalline basement where earthquakes occur. Most of the studies described above have had to rely on mathematical modeling to infer critical pressure conditions within the crystalline basement associated with induced seismicity due to the dearth of available pore pressure data.

Crystalline basement rock permeability can be inferred using a variety of methods, including hydraulic tests from deep boreholes (Brace 1984; Stober \& Bucher 2007; Fig. 2), fracture aperture measurements on outcrops (Snow 1968; Caine \& Tomusiak 2003; Klimczak et al. 2010), and temperature anomalies associated with regional groundwater flow systems within the crystalline basement (e.g., Forster \& Smith 1989; Mailloux et al. 1999; Manning \& Caine 2007; Pepin et al. 2015). Synthesis studies of deep borehole hydraulic tests suggest that crustal permeability is scale dependent (Clauser 1992) and decays with depth (Stober \& Bucher 2007) with non-negligible $\left(10^{-18}\right.$ to $\left.10^{-19} \mathrm{~m}^{2}\right)$ permeability below the brittle-ductile transition (Manning \& Ingebritsen 1999; Ingebritsen \& Gleeson 2015; Fig. 2 curve A). Townend \& Zoback (2000) argued that the presence of hydrostatic pressure conditions and numerous observations of temperature anomalies associated with fracture planes in deep boreholes indicate bulk permeability of crystalline basement rocks ranging between $10^{-16}$ and $10^{-17} \mathrm{~m}^{2}$ on average. Petrologists, economic geologists, and geophysicists have argued for some time that permeability can behave dynamically within the crystalline basement. This transience takes the form of permeability increases due to seismic activity followed by permeability reductions as a result of fluid-rock interactions, such as pressure solution and mineral precipitation (Lowell et al. 1993; Manga et al. 2012). Ingebritsen \& Manning (2010) proposed that geologic forcing (e.g., regional tectonic stress) could increase crustal permeability by about two orders of magnitude (Fig. 2 curve B). It seems likely that the injection of large volumes of oil-field brines into basal reservoirs may provide hydrogeologists with new opportunities to constrain dynamic crystalline basement permeability.

Southeastern New Mexico has experienced increased seismicity between 1999 and 2012 within the Permian basin adjacent to the Dagger Draw oil field (Edel et al. 2016; Figs 3 and 4). Seismicity within the crystalline basement in this region occurs at depths that range from 5 to $19 \mathrm{~km}$, with a mean depth of $11 \mathrm{~km}$ (Edel et al. 2016; Fig. 1A). The epicenter of the seismicity occurs about $85 \mathrm{~km}$ from the low-level nuclear Waste Isolation Pilot Plant near Carlsbad, NM (WIPP, blue circle in Fig. 3A). Beneath the Dagger Draw oil field, saline water is injected into the basal Ellenburger carbonate reservoir, which rests

Table 1 Injection, seismicity, and fluid pressure data from case studies documenting Instances of induced seismicity across the USA.

\begin{tabular}{|c|c|c|c|c|c|}
\hline Location & Basal reservoir name & $\begin{array}{l}\text { Max. earthquake } \\
\text { magnitude/Average } \\
\text { hypocenter depth }(\mathrm{km})\end{array}$ & $\begin{array}{l}\text { Maximum } \\
\text { cumulative } \\
\text { injection rate } \\
\text { (Millions } \\
\text { Barrels/month)** }\end{array}$ & $\begin{array}{l}\text { Wellhead } \\
\text { fluid pressure } \\
\text { increase }(\mathrm{MPa})\end{array}$ & $\begin{array}{l}\text { Maximum } \\
\text { lateral distance } \\
\text { between injection } \\
\text { wells and } \\
\text { seismicity }(\mathrm{km})\end{array}$ \\
\hline Youngstown, $\mathrm{OH}^{*}$ & Crystalline Basement & $3.9 / 3.7$ & 0.15 & 7 & 1 \\
\hline Jones, OK & Arbuckle Limestone & $3 / 4.5$ & 18 & 1 & 35 \\
\hline Guy, $A K^{*}$ & Ozark & $4.7 / 5$ & 1.8 & 11.8 & 15 \\
\hline Prague, $\mathrm{OK}^{\S \oplus}$ & Arbuckle Limestone & $5.7 / 5$ & 0.6 & 3.7 & 15 \\
\hline Dagger Draw, NM & Ellenberger Limestone & $3.2 / 11$ & 3 & - & 15 \\
\hline Rocky Mountain Arsenal & Crystalline Basement & $5.5 / 5$ & 0.19 & 7.2 & 5 \\
\hline
\end{tabular}

*Kim (2013), single injection well production reported, North Star-1. †Keranen et al. (2014). "Horton (2012). ${ }^{\S}$ Keranen et al. (2013). ${ }^{\circledR}$ Walsh \& Zoback (2015). ${ }^{*}$ Cumulative injection refers here to the summation of injection rates of all wells within a given area of study (spatial summation). That said, we note that the Youngstown, Ohio study of Kim (2013) only presented injection data for 1 well. 
Fig. 1. Generalized geologic cross sections showing locations of oil-field brine reinjection wells and associated seismicity within the crystalline basement in New Mexico (A, Edel et al. 2016), Arkansas (B, Horton 2012); Ohio (C, Kim, 2013); and Oklahoma (D, Keranen et al. 2013).

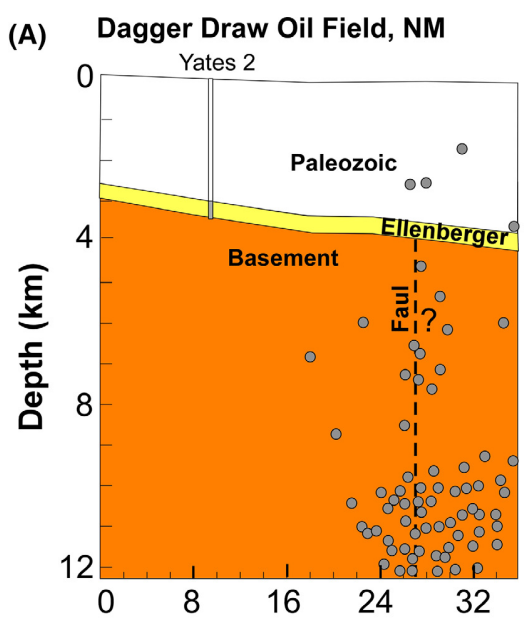

(B) Guy Arkansas, AK
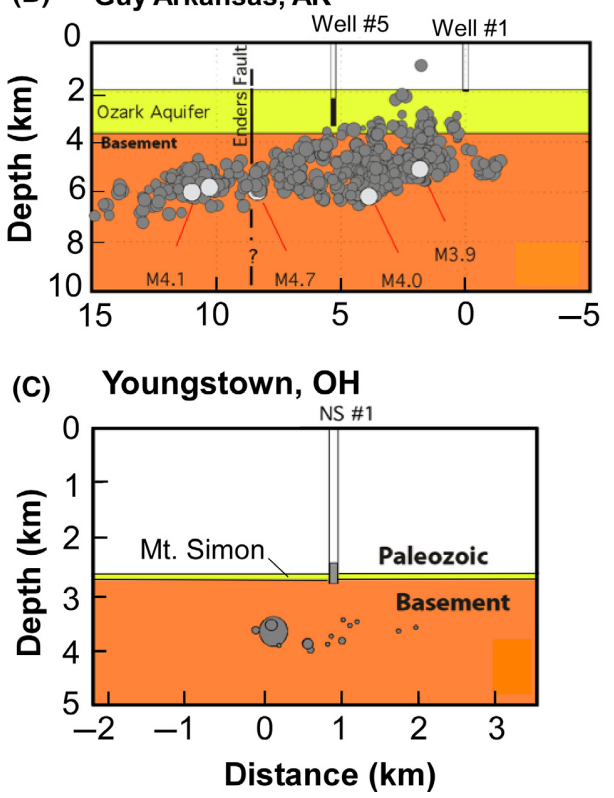

(D) Prague, Oklahoma

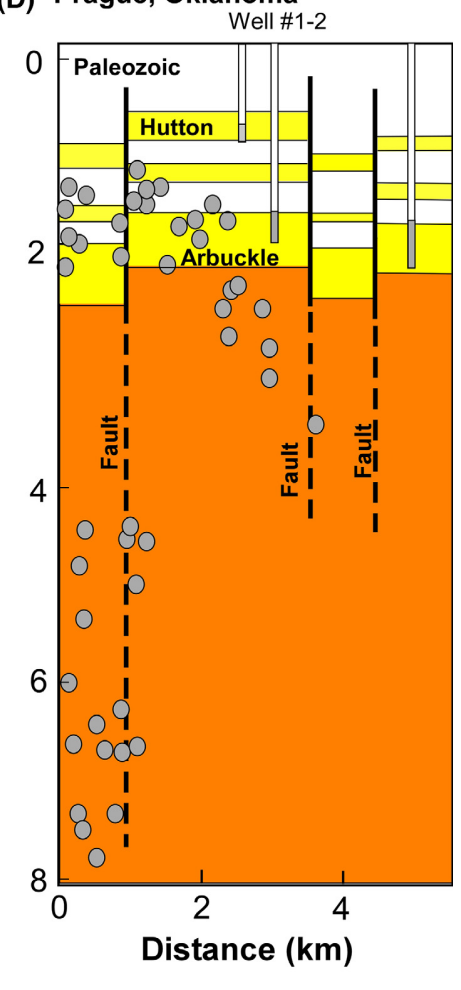

unconformably on the crystalline basement. There are relatively high injection rates (over 1 million barrels per month) in wells within $20 \mathrm{~km}$ of the seismic cluster (Fig. 3B). In their analysis of seismicity across the USA, Weingarten et al. (2015) inferred from analysis of regional data sets that there is a significant correlation between induced seismicity and high injection rates (>300 000 barrels per month). The relationship between seismicity and brine injection is less straightforward in southeastern New Mexico than with some of the above examples listed in Table 1. Typically, one expects to see a close temporal correlation between seismicity and fluid injection (e.g., Hsieh \& Bredehoeft 1981). In the case of the Dagger Draw oil field, peak injection occurred in 1996. Seismicity increased around 2001, 5 years after peak injection (Fig. 4A). Limited regional seismic observations go back to the mid1970s, with a larger network of 7-9 stations in place by
1998. Relocation of recent seismicity suggests hypocenters in this region are deeper (Fig. 5) than any of the other published instances of triggered seismicity (Table 1). Finally, the hypocenter of the seismicity is not directly beneath the oil field but is $15 \mathrm{~km}$ to the west (Figs 1A and $3 \mathrm{~B}$ ). Many of the epicenters line up in a more or less north-south trend (Figs $3 \mathrm{~A}$ and 5 ). In some scenarios presented below, we consider the effects of a north-southoriented conductive fault zone west of the Dagger Draw oil field.

\section{DAGGER DRAW OIL FIELD GEOLOGY, PRODUCTION, AND INJECTION HISTORY}

The Dagger Draw oil field lies on the edge of the Permian Basin in southeastern New Mexico. Production began in 1969 (Fig. 4A) primarily out of the Canyon (Missourian) 


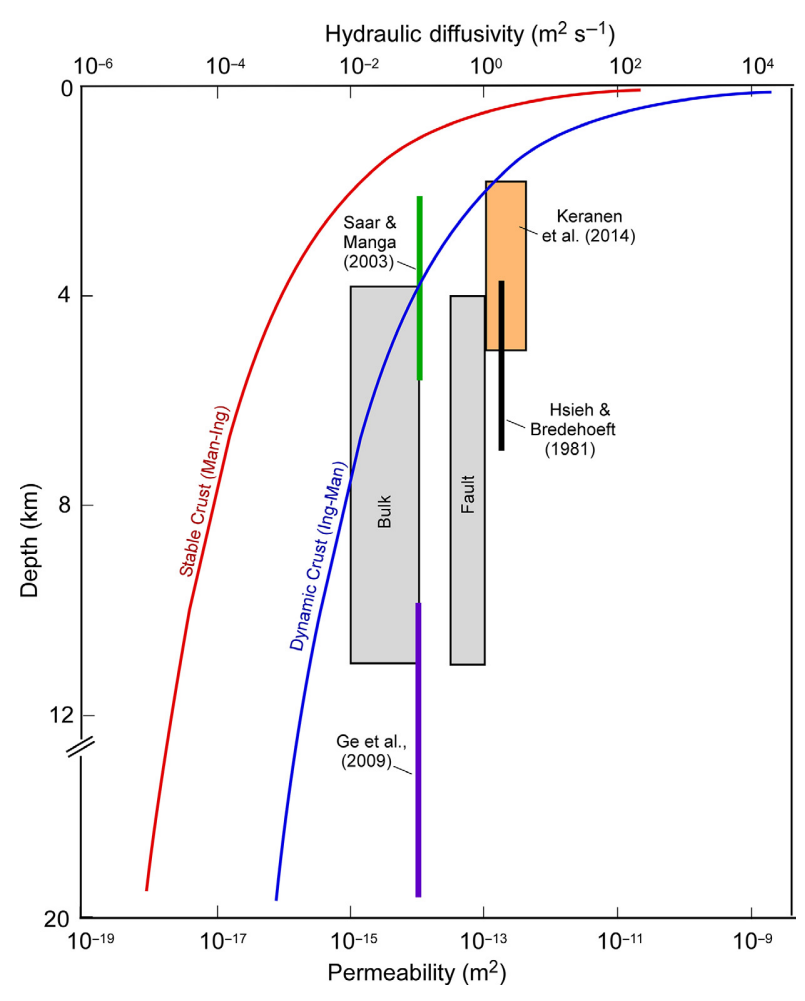

Fig. 2. Hydraulic diffusivities derived from model reconstructions of triggered seismicity studies and inferred from geophysical, petrological, and geophysical data (black and blue lines). The red permeability-depth curve is from Manning \& Ingebritsen (1999). The blue permeability decay curve is from Ingebritsen \& Manning (2010). The permeability axis assumes a specific storage coefficient of $10^{-6} \mathrm{~m}^{-1}$. The gray boxes are hydraulic diffusivities reported in this study for the Dagger Draw oil field in southeastern New Mexico.

and Cisco (Virgilian) Groups that, in the Dagger Draw field, consist of upper Pennsylvanian reefal limestones (Broadhead 1999). The oil is stratigraphically trapped in this carbonate unit and overlain by low-permeability shales in the Permian Hueco Formation and underlain by the Barnett and Woodford shales (Fig. 6; Broadhead 1999). There are currently 138 producing wells in the Dagger Draw field, down from a peak of 414 producing wells in 2001 [GoTech; New Mexico Oil Conservation Division database (www.gotech.nmt.edu)]. About 2-3 times as much brine is produced as oil by volume (Fig. 4A), generally appearing as brackish water with TDS contents between 4000 and $10000 \mathrm{mg}^{-1}$ and a maximum salinity in some areas as high as $309000 \mathrm{mg} \mathrm{l}^{-1}$ (Balch \& Muraleedharan 2014).

Produced oil-field brine is primarily injected into the basal Ellenburger Group. There is also some injection of oil-field brines into the overlying Montoya, Fusselman, and Wristen carbonate units. Within the Dagger Draw oil field, permitted wellhead injection pressures for these formations range between about $1520 \mathrm{~m}$ and $1670 \mathrm{~m}$ for reservoir depths ranging between 3.3 and $3.6 \mathrm{~km}$ (New Mexico Oil
(A)

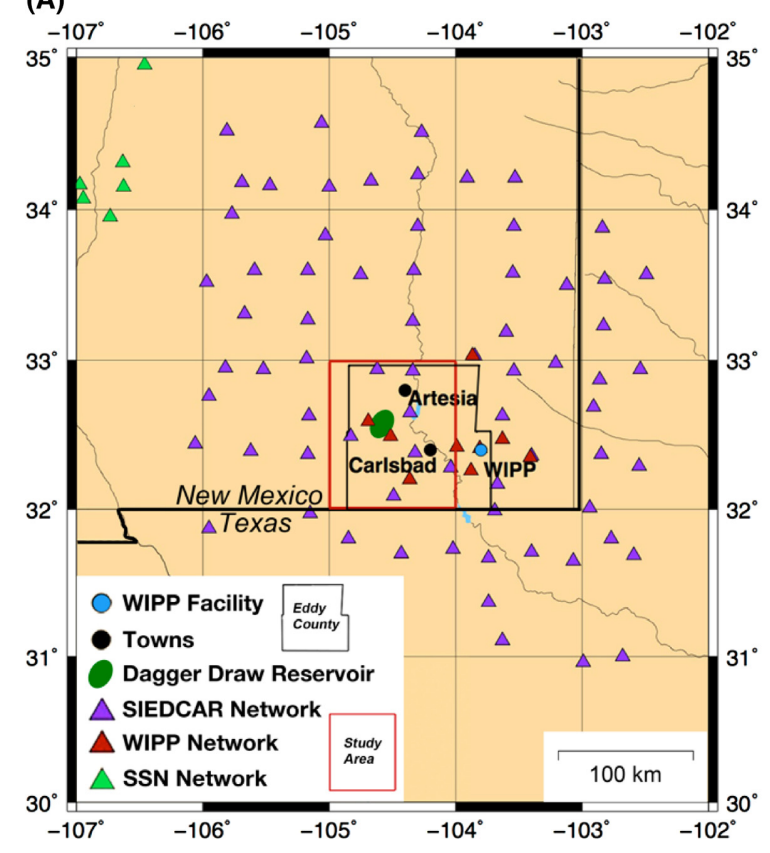

(B)

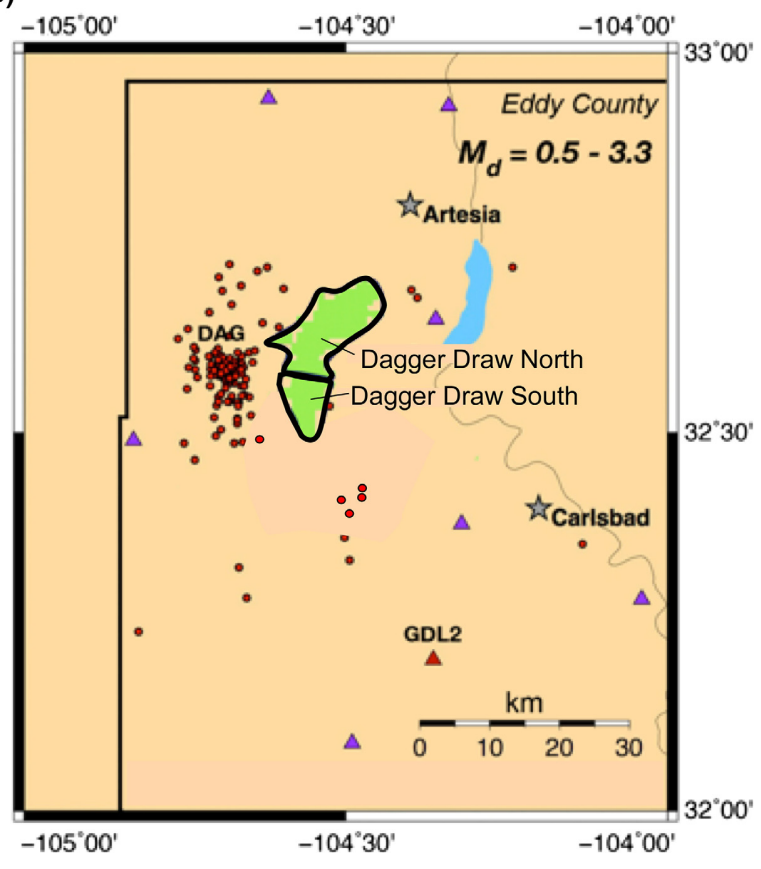

Fig. 3. (A) Study area map showing WIPP seismic (red triangles), SIEDCAR (purple triangles), Socorro Seismic Network (SSN, green triangles) location of the WIPP site and Dagger Draw (dark green blob) oil field in Eddy County, New Mexico. The location of the WIPP site is indicated by the blue circle. (B) Relocated epicenters (small red circles) for 203 earthquakes between 2008/09 and 2010/07 relative to the location of the Dagger Draw oil field. Oil field locations (green shaded areas) are courtesy of the New Mexico Bureau of Geology, reservoir outline from Speer (1993).

Conservation Division, 2016). The Ellenburger thickness in New Mexico ranges from about 1 to $70 \mathrm{~m}$ (Holtz \& Kerans 1992). Ellenburger Limestone thickness increases 


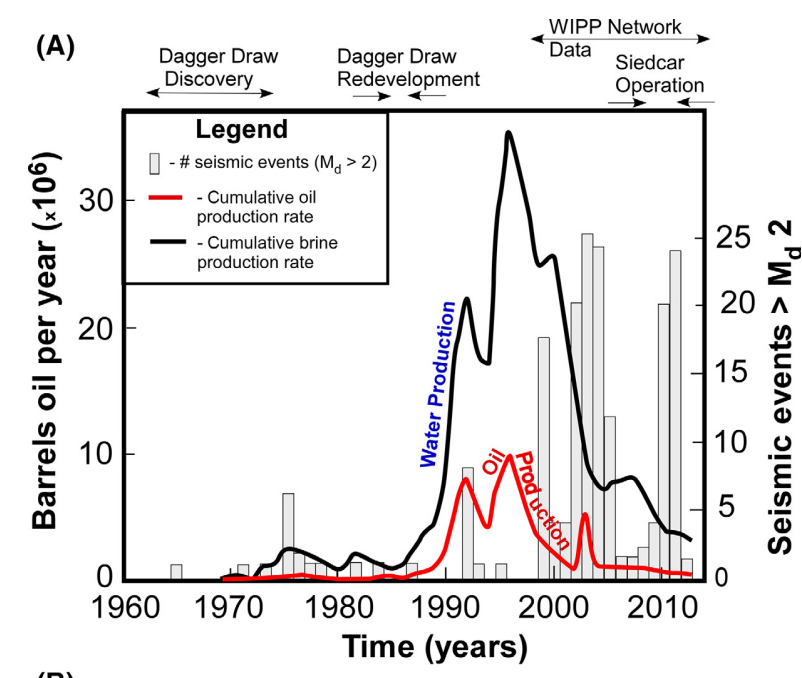

(B)

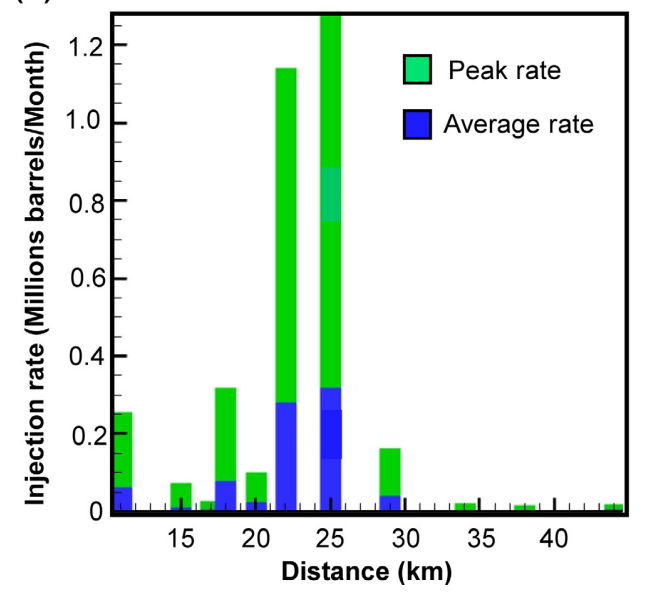

Fig. 4. (A) Annual production of oil and saline brines (water) from the Dagger Draw Oil Field, Permian Basin, and seismic events greater than M2. (B) Average and maximum injection rates for the 15 injection well centers versus distance from the centers to the centroid of seismicity (after Edel et al. 2016).

to the southeast in Texas (Fig. 6; Wright 1979). Porosity varies from 0.01 to 0.2 with an average of about 0.06 . Core permeability values range from 2 to $100 \mathrm{mD}\left(10^{-15}\right.$ to $10^{-13} \mathrm{~m}^{2}$; Loucks 2003). The Ellenburger experienced multiple episodes of karstification and dolomitization which likely enhanced its effective formation permeability above core measurements (Cox et al. 1998; Broadhead 1999). In our numerical sensitivity study, we assign permeabilities to the Ellenburger ranging from $10^{-14}$ to $10^{-12} \mathrm{~m}^{2}$. If bulk permeability is higher than $1000 \mathrm{mD}$ due to the karst- and solution-enhanced porosity, the results presented (using $10^{-12} \mathrm{~m}^{2}$ ) here would be an upper bound on calculated excess pressures.

Initial oil and produced water production was low until the early 1990s when the field was redeveloped. Peak production was in 1996 and the field has seen declining production ever since. The Dagger Draw field initially

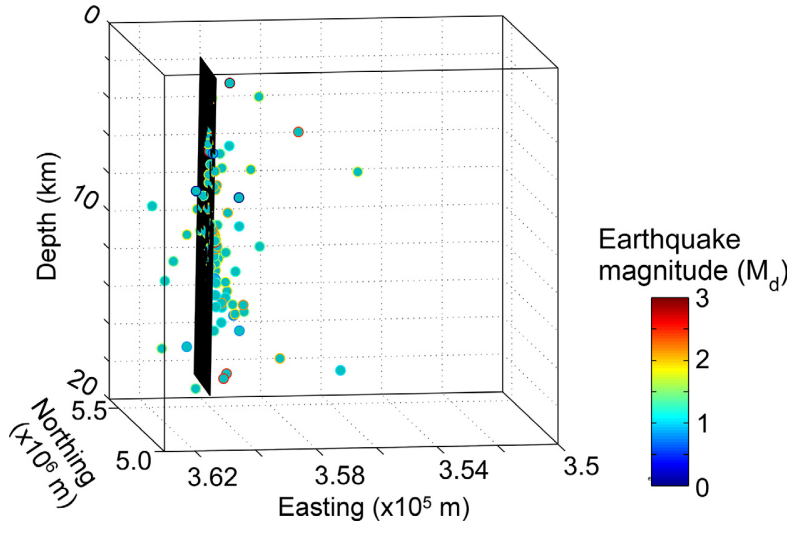

Fig. 5. Three-dimensional view (looking north) showing relocated hypocenter depths for seismicity from 2008/09 to 2010/07 adjacent to the Dagger Draw Oil Field, Permian Basin, New Mexico. Sphere color indicates magnitude (up to $M_{d}$ 3.2). Depth errors range between 1.4 and $6 \mathrm{~km}$. Hypocenter data from Edel et al. (2016). Black surface indicates position of fault plane used in hydrogeologic model.

consisted of two fields, Dagger Draw North (DDN) and Dagger Draw South (DDS; Fig. 3B). The fields were originally developed separately and were thought to have independent geologic boundaries. Low permeable Upper Pennsylvanian carbonates in the uppermost part of the Cisco section and the overlying Hueco Formation provide the top seal for the Upper Pennsylvanian reservoir at Dagger Draw. The Woodford Shale (Devonian) provides the top seal for the Wristen (Silurian) carbonates. Carbonate reservoirs in the Fusselman (Silurian; underlies the Wristen), the Montoya, and the Ellenburger limestones are self-sealed by impermeable carbonate strata within those units. The Hueco Formation, the Barnett, and Woodford Shales with the intervening Lower Mississippian limestone form the top seal for the Ellenburger, Montoya, Fusselman, and Wristen carbonate sequence in the Dagger Draw area.

We focus our analysis on 83 reinjection wells within $20 \mathrm{~km}$ of the seismicity in Eddy County, New Mexico. Oil and water production data were taken from New Mexico Oil Conservation Division reports (1969-2003) as well as the GoTech database (2004-2013). Monthly production data of oil, gas, and water were summed for all wells in each township/range section and then compared to the monthly earthquake frequency $\left(\mathrm{M}_{\mathrm{d}}>2\right.$; Fig. 4A). For our modeling effort, the 83 individual oilfield brine reinjection wells were lumped into 15 regions (injection nodes) by township and range (Table 2 ). That is, the 83 injection wells were represented by consolidating them into 15 injection nodes in our model. For some injection nodes, peak reinjection rates exceeded 1 million barrels per month (Fig. 4B). The approximate center of seismic activity coincides with T20S R23E in western Eddy County NM, $15 \mathrm{~km}$ west of the Dagger Draw oil field (Fig. 3). 

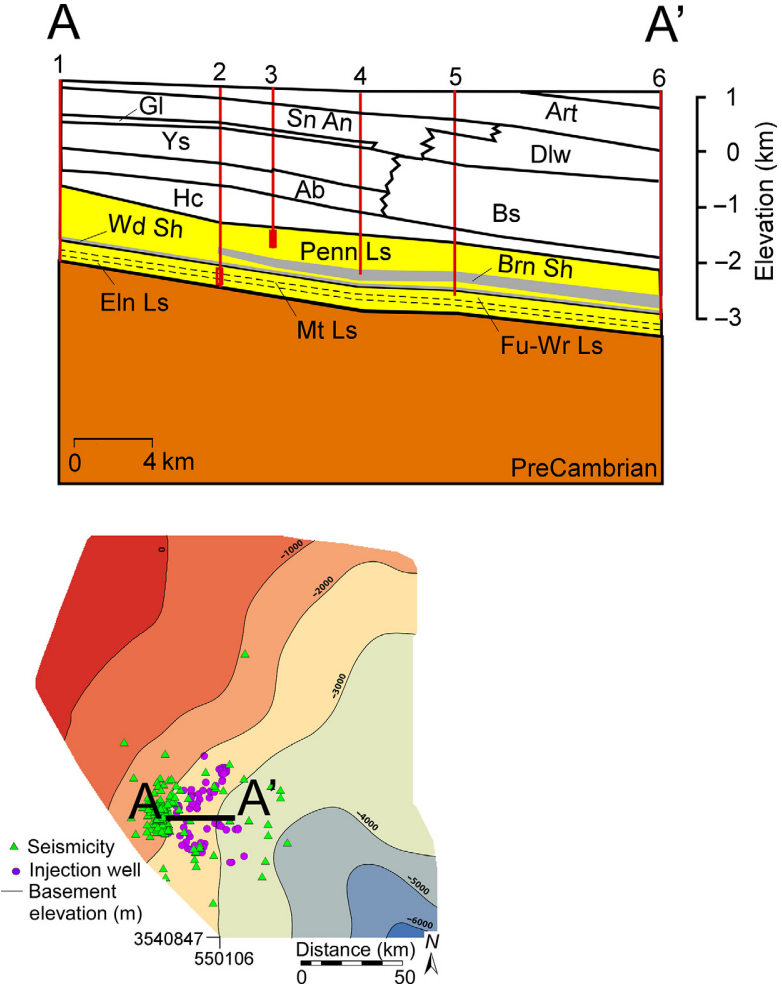

Fig. 6. Contour map of crystalline basement elevation (in $\mathrm{m}$, sea-level datum) surrounding the Dagger Draw oil field in southeastern NM. The locations of the 83 oil-field brine reinjection wells (purple circles) and seismicity (green triangles) are shown on the contour map. A geologic cross section across the Dagger Draw oil field is also shown. Oil production occurs primarily within Pennsylvanian carbonates (Penn Ls, yellow). Oil-field brine reinjection occurs in the basal Ellenberger Group (EI), Montoya Limestone (Mt), and Fusselman and Wristen limestone units (Fu-Ws, yellow) Additional geologic units include the following: Brn Sh, Barnett Shale (gray); Wd Sh, Woodford Shale (gray); Hc Hueco Formation; Ab Abo formation; Ys, Yeso Formation; Gl, Glorietta Sandstone; Sn An, San Adres formation; Art, Artesia Group. Red numbered lines show well control; 1- Southern Union Production Corp. No. 1 Elliot, 24-18S-23E; 2- Yates Petroleum No. 3 Roy AET WD, 7-19S- 25E; 3- Yates Drig. No. 1 Rodke AOY 21-19S-25E; 4- Northern Natural Gas, No. 1 Moutray, 6-20S-26E; 5- S.P. Yates No. 4, Pecos River Deep Unit, 11-20S-26E; 6 Oxy USA No. 1 Govt NBFD 11-20S26E. Plan view map shows approximate location of cross section, production wells (red squares) and seismicity (green triangles). Injection interval illustrated schematically using red rectangle at the bottom of two wells.

\section{ANALYSIS OF SEISMIC AND OIL-FIELD REINJECTION DATA}

Edel et al. (2016) analyzed the hypocenter locations of earthquakes in the vicinity of the Dagger Draw oil field between 1962 and 2013. Prior to 1998, the number of New Mexico Tech (Socorro) Seismic network seismic stations was relatively low. Seven to nine vertical-component short-period seismic stations began operating in 1998. Edel et al. (2016) relocated earthquakes from 2008 to 2011 using data from this network as well as
Table 2 Locations, reinjection rates, and lateral distance to the center of seismicity for each of the 15 injection well centers. The township $(T)$ and range $(R)$ of each injection center are indicated by the ID.

\begin{tabular}{llllll}
\hline Section ID & $\begin{array}{l}\text { Easting } \\
(\mathrm{m})\end{array}$ & $\begin{array}{l}\text { Northing } \\
(\mathrm{m})\end{array}$ & $\begin{array}{l}\text { Maximum } \\
\text { (Barrels/ } \\
\text { month) }\end{array}$ & $\begin{array}{l}\text { Average } \\
\text { (Barrels/ } \\
\text { month) }\end{array}$ & $\begin{array}{l}\text { Distance } \\
(\mathrm{km})\end{array}$ \\
\hline T22S R26E & 567254 & 3581357 & $2.0 \mathrm{E}+05$ & $4.57 \mathrm{E}+04$ & 44 \\
T22S R24E & 548426 & 3586558 & $1.0 \mathrm{E}+07$ & $3.17 \mathrm{E}+06$ & 25 \\
T2S 2R23E & 540024 & 3585734 & $5.0 \mathrm{E}+05$ & $1.32 \mathrm{E}+05$ & 20 \\
T21R26 & 566023 & 3596084 & $8.0 \mathrm{E}+04$ & $1.88 \mathrm{E}+04$ & 38 \\
T21R25 & 557571 & 3597820 & $2.0 \mathrm{E}+06$ & $4.05 \mathrm{E}+05$ & 29 \\
T21R24 & 546987 & 3590619 & $1.0 \mathrm{E}+07$ & $2.81 \mathrm{E}+06$ & 22 \\
T20R25 & 546535 & 3607245 & $3.0 \mathrm{E}+06$ & $7.85 \mathrm{E}+05$ & 18 \\
T20R24 & 539417 & 3605254 & $3.0 \mathrm{E}+06$ & $6.30 \mathrm{E}+05$ & 11 \\
T19R26 & 555433 & 3613893 & $1.0 \mathrm{E}+06$ & $2.62 \mathrm{E}+05$ & 29 \\
T19R25 & 546645 & 3612400 & $1.0 \mathrm{E}+06$ & $2.51 \mathrm{E}+05$ & 20 \\
T19R24 & 541546 & 3614440 & $3.0 \mathrm{E}+05$ & $6.43 \mathrm{E}+04$ & 17 \\
T18R26 & 560699 & 3624065 & $2.0 \mathrm{E}+05$ & $3.91 \mathrm{E}+04$ & 38 \\
T18R25 & 552183 & 3618446 & $2.0 \mathrm{E}+05$ & $3.46 \mathrm{E}+04$ & 28 \\
T17R25 & 551112 & 3630933 & $3.0 \mathrm{E}+04$ & $6.32 \mathrm{E}+03$ & 36 \\
T21R23 & 538540 & 3591748 & $7.0 \mathrm{E}+05$ & $9.64 \mathrm{E}+04$ & 15 \\
\hline
\end{tabular}

the 3-component broadband EarthScope Flexible Array (SIEDCAR) campaign (Fig. 3A). Relocated seismic events cluster in an area of about $10 \mathrm{~km}$ diameter with its center located approximately $15 \mathrm{~km}$ from the nearest injection wells of the Dagger Draw oil field. The majority of earthquakes occurred at $10-12 \mathrm{~km}$ depth (Fig. 5) with depth errors between 1.4 and $6 \mathrm{~km}$. Seismic events prior to 2008 were not relocated. Some of the hypocenters appear to line up along a high-angle fault plane. Edel et al. (2016) noted that there is a lag of at least 5 years between peak injection in 1996 and increases in seismicity frequency $15 \mathrm{~km}$ to the west of the Dagger Draw oil field in 2001 (Fig. 4A). Edel (2015) hypothesized that a conductive fault zone with a variable dip between 45 and 80 may provide a conduit for elevated fluid pressures. Given the long lateral distance $(15 \mathrm{~km})$ and large depth $(11 \mathrm{~km})$ between the earthquake hypocenters and the Dagger Draw oil field injection wells, it seems plausible that a significant lag occurred between the time of peak injection and the time when seismicity increased.

\section{PURPOSE OF STUDY}

The main goal of this study is to assess what reservoir and crystalline basement permeability scenarios could produce a 5-year time lag of fluid pressure increases above $0.07 \mathrm{MPa}(7 \mathrm{~m}$ of excess head) at a depth of $11 \mathrm{~km}$ in the crystalline basement to the west of the Dagger Draw oil field. We do not have measured pressure data within the crystalline basement beneath the Dagger Draw oil field to establish the $7 \mathrm{~m}$ head threshold. However, this head value falls within the range of what has been used by prior studies as a triggered seismicity threshold. A secondary goal of this study was to assess different pressure 
management scenarios that might reduce pressures within the crystalline basement by redistributing and/or lowering the injection rates at various reinjection wells. In the absence of pressure data within the crystalline basement, hydrologic modeling represents a powerful tool to address these questions. However, hydrologic model results are nonunique and cannot be validated (Konikow \& Bredehoeft 1992; Oreskes et al. 1994). There is also uncertainty in representing permeability of the crystalline basement as a bulk parameter as opposed to a discrete fracture network.

\section{METHODS}

We developed a three-dimensional hydrogeologic model to simulate injection into the Ellenburger Group at Dagger Draw (Fig. 7) and pressure diffusion into the crystalline basement using the United States Geological Survey's groundwater model, MODFLOW (Harbaugh \& McDonald 1996). Bulk crystalline basement permeability is related to the square of the aperture spacing of interconnected fracture planes (Snow 1968; Schwartz \& Zhang 2003). Because of the large spatial length scales represented in this
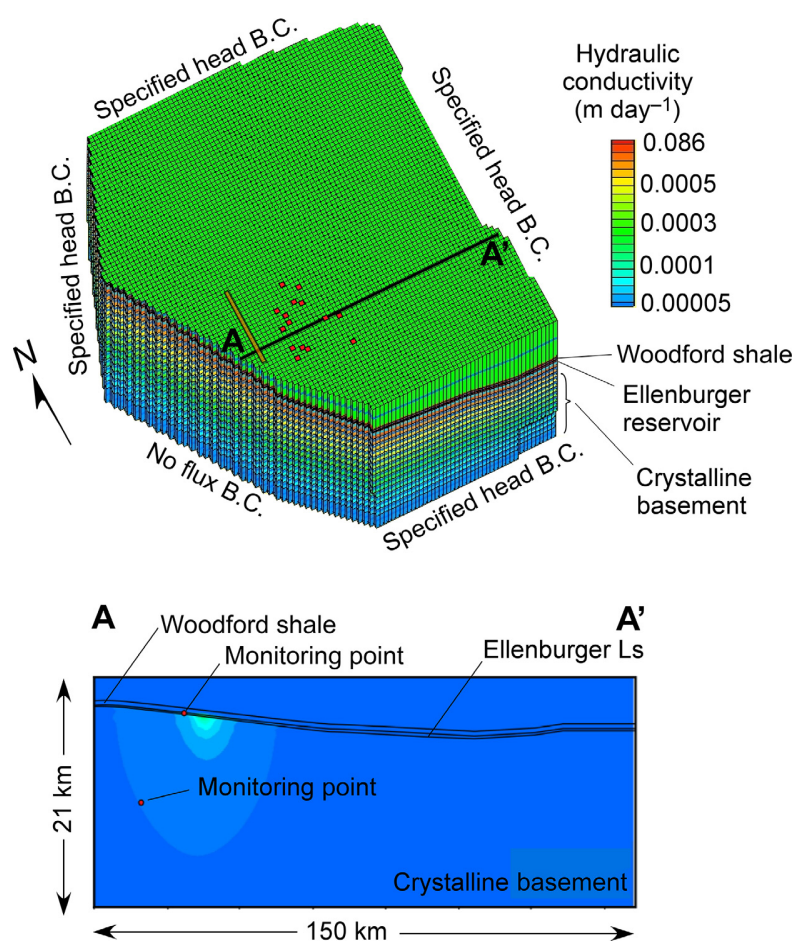

Fig. 7. Three-dimensional view of MODFLOW finite difference grid and the east-west cross section $A-A^{\prime}$ showing locations of two monitoring points used in sensitivity study. The red squares denote the lateral position of the reinjection wells within the Ellenburger Limestone (layer 9) projected up onto the top layer. The thin orange line denotes the lateral position of a fault zone with relatively high permeability within the crystalline basement projected up onto the top layer (layers 10-25). study, it was not computationally possible to represent a distributed fracture network (Bogdanov et al. 2003; Neuman 2005). MODFLOW solves the following groundwater flow equation:

$$
\begin{gathered}
\frac{\partial}{\partial x}\left(K_{x} \frac{\partial h}{\partial x}\right)+\frac{\partial}{\partial y}\left(K_{y} \frac{\partial h}{\partial y}\right)+\frac{\partial}{\partial z}\left(K_{z} \frac{\partial h}{\partial z}\right) \\
=S_{s} \frac{\partial h}{\partial t}+\mathcal{Q}(x, y, z, t)
\end{gathered}
$$

where $h$ is the freshwater hydraulic head [L], $K$ is the hydraulic conductivity tensor $\left[\mathrm{L} t^{-1}\right], S_{s}$ is specific storage $\left[\mathrm{L}^{-1}\right], Q$ is fluid injection source term $\left[t^{-1}\right]$, and $t$ is time $[t]$.

We imposed a constant head boundary $(h=1100 \mathrm{~m})$ along the top of the model domain (Fig. 7). This value represents an average land surface elevation for this part of the Permian Basin. We did this so that the effects of injection could be more conspicuous. Additionally, a specified head boundary condition was set along the north, west, south, and west-northeast side boundaries $(b=1100 \mathrm{~m})$. If we had imposed head gradient across the model domain's lateral boundaries reflecting topographic variations in the water table, then it would have been more difficult to visualize head changes due to injection as opposed to head changes cause by lateral flow. A no-flux boundary was set along the base of the model and along the southwest boundary, where a relatively large displacement fault was observed in the surface geologic map of Eddy County, NM. The no-flux boundary allows heads to build up higher than they would if the fault was absent. Overall, these boundary conditions are somewhat idealized. We set the domain far enough away from the injection wells that, with the exception of the no-flux southwest boundary, the simulated head increases were not significantly affected by the constant head boundaries.

The total vertical thickness of the model is $21.1 \mathrm{~km}$. In plan view, the model domain footprint is $200 \times 200 \mathrm{~km}$. A uniform lateral grid discretization was used in this study. Preliminary simulations using locally refined (telescoping) grids failed to converge when large permeability contrasts were represented. When a uniform grid was used, no convergence issues were encountered. We used a total of 95 columns, 100 rows, and 24 layers to represent the basin sedimentary rocks (maximum depth $4.4 \mathrm{~km}$ ) and the underlying crystalline basement. Using a uniform grid allowed us to represent a greater than five order of magnitude contrast in hydraulic conductivity between the Ellenberger reservoir $\left(0.86 \mathrm{~m} \mathrm{day}^{-1}\right)$ and the Barnett Shale $\left(0.000003 \mathrm{~m} \mathrm{day}^{-1}\right)$. Each finite difference cell had lateral dimensions of about 2.1 by $2.3 \mathrm{~km} \mathrm{(} \Delta \mathrm{x}$ by $\Delta \mathrm{y}$, respectively). Vertical cell size varies considerably. We lumped the Barnett and Woodford Shales into a single 100-mthick confining unit that was discretized using five layers $(\Delta \mathrm{z}=20 \mathrm{~m})$. We lumped the Ellenburger Montoya, 
Fusselman, and Wristen carbonate units into a single layer. The layer thickness varied from 1 to $247 \mathrm{~m}$ with an average thickness of $85 \mathrm{~m}$. All injection took place in this layer. A total of 15 layers were used to represent the crystalline basement. The thickness of each crystalline basement layer varied from about $870 \mathrm{~m}$ to $1280 \mathrm{~m}$.

An important concern when using numerical models is whether or not the solution domain is sufficiently discretized to accurately capture the hydrodynamics of a given problem. If increasing grid refinement causes significant changes in computed hydraulic heads, then the discretization should be increased. To assess how grid size affected simulated heads, we varied the lateral discretization by a factor of three (see Appendix S1 for details). We found that increasing the lateral discretization of the reservoir from about $2 \mathrm{~km}$ on a side $(100 \times 100$ cells $)$ to about $730 \mathrm{~m}$ on a side $(300 \times 300$ cells) resulted in a $20 \%$ increase in the maximum computed heads in the injection well centers. Near the no-flow boundary, head changes were largely unchanged for the three model runs (see Appendix S1).

Because some of the earthquake hypocenters lined up, more or less, along a subvertical planar surface (Fig. 5), we constructed two hydrologic models that included a relatively permeable $\left(10^{-14}\right.$ to $\left.10^{-15} \mathrm{~m}^{2}\right)$ vertical fault plane. These two simulations included a north-south trending vertical fault zone of one cell width and $46 \mathrm{~km}$ in length (north-south) within the crystalline basement.

The models were run using a time step of 1 month for 45 years (540 months) between 1969 and 2013 using production data from the reinjection wells within a $20 \mathrm{~km}$ radius of the seismic cluster. Monthly oil-field brine production from the 416 production wells were reinjected into the Ellenburger group limestone layer using 15 wells for each model simulation. The maximum and average injection rates for each of the 15 well centers are listed in Table 2 .
We systematically varied the permeability of the crystalline basement and reservoir in a sensitivity study to determine what range of permeabilities could plausibly lead to head changes that could trigger seismicity (Table 3 ). The specific storage was not varied in the sensitivity study between model runs nor was the permeability of the three uppermost units (Table 4). Cross-sectional and plan view model results are discussed below for 15 scenarios. We monitored head changes at $11 \mathrm{~km}$ depth in the center of the region of seismicity and within the Ellenburger Group (red dots in cross section at the bottom of Fig. 7).

\section{RESULTS}

\section{Effects of crystalline basement permeability variations (Scenarios 1-4)}

We begin our analysis by considering how variations in bulk crystalline basement permeability affect the downward propagation of the fluid pore pressure. We varied the bulk permeability of the crystalline basement from $10^{-15}$ to $10^{-16} \mathrm{~m}^{2}$. The permeability values we have used in this study are one order of magnitude higher than what are considered typical conditions by Townend \& Zoback (2000) for the crystalline basement.

While our model is three-dimensional, we focus our analysis on the head changes within the crystalline basement along an east-west cross section $\mathrm{A}-\mathrm{A}^{\prime}$ (Fig. 7). In all simulations, pore pressure increases are due to oil-field brine injection within the Ellenburger Group (including the Montoya, Fusselman, and Wristen carbonates) over the time period between 1969 and 2013 (Fig. 8). Production in the overlying Pennsylvanian limestone reservoir unit was neglected. In all of these simulations, the Ellenburger permeability is set at $10^{-12} \mathrm{~m}^{2}$ and the overlying confining

Table 3 Permeability (in $\mathrm{m}^{2}$ ) using in different hydrologic model runs (scenarios) for selected units.

\begin{tabular}{|c|c|c|c|c|c|}
\hline Scenario & $\begin{array}{l}\text { Ellenburger } \\
\text { limestone }\end{array}$ & $\begin{array}{l}\text { Crystalline } \\
\text { basement }\end{array}$ & $\begin{array}{l}\text { Fault } \\
\text { zone }\end{array}$ & $\begin{array}{l}\text { Injection } \\
\text { strategy }\end{array}$ & Figures \\
\hline 1 & $10^{-12}$ & $10^{-16}$ & - & Obs* & $8 \mathrm{~A}, 8 \mathrm{D}, 9,10$ \\
\hline 3 & $10^{-12}$ & $10^{-15}$ & - & Obs & $\begin{array}{l}8 \mathrm{C}, 8 \mathrm{~F}, 9,10,11 \mathrm{~A}, 11 \mathrm{D}, \\
12 \mathrm{~A}, 12 \mathrm{D}, 13,16 \mathrm{~A}, 16 \mathrm{D}, 17\end{array}$ \\
\hline 4 & $10^{-13}$ & $10^{-15}$ & - & Obs & $11 \mathrm{~B}, 11 \mathrm{E}, 12 \mathrm{~B}, 12 \mathrm{E}, 13$ \\
\hline 5 & $10^{-14}$ & $10^{-15}$ & - & Obs & $11 \mathrm{C}, 11 \mathrm{~F}, 12 \mathrm{C}, 12 \mathrm{~F}, 13$ \\
\hline 6 & $10^{-12}$ & $10^{-16}$ & $10^{-14}$ & Obs & $14 \mathrm{~A}, 14 \mathrm{E}, 15$ \\
\hline 7 & $10^{-12}$ & $10^{-16}$ & $10^{-15}$ & Obs & $14 \mathrm{~B}, 14 \mathrm{~F}, 15$ \\
\hline 8 & $10^{-12}$ & $10^{-16}$ & $3 \times 10^{-15}$ & Obs & 15 \\
\hline 9 & $10^{-12}$ & $10^{-12.8}$ to $10^{-17}$ & - & Obs & $14 C, 14 G, 15$ \\
\hline 10 & $10^{-12}$ & $10^{-14.8}$ to $10^{-19}$ & - & Obs & $14 \mathrm{D}, 14 \mathrm{H}, 15$ \\
\hline 11 & $10^{-12}$ & $10^{-15}$ & - & $\mathrm{Ave}^{\dagger}$ & $16 \mathrm{~B}, 16 \mathrm{E}, 17$ \\
\hline 12 & $10^{-12}$ & $10^{-15}$ & - & $\mathrm{Wgt}^{+}$ & $16 \mathrm{C}, 16 \mathrm{~F}, 17$ \\
\hline 13 & $10^{-12}$ & $10^{-15}$ & - & $50 \%{ }^{\S}$ & 17 \\
\hline
\end{tabular}

* Simulation uses observed pumping history shown in Fig. 4A. 'Simulation uses monthly average pumping rate assigned to each well. ${ }^{\star}$ Simulation uses weighted pumping rate. Wells closest to the southwestern no-flux boundary are assigned a lower pumping rate. Wells furthest from the no-flux boundary see their pumping rates increased. ${ }^{\S}$ Simulation uses reduced (in percent) pumping rates relative to the observed levels. 
Table 4 Hydrogeologic properties for hydrostratigraphic units that are not varied between model runs.

\begin{tabular}{lcc}
\hline Formation Name & $K\left(\mathrm{~m}^{2}\right)$ & $S_{s}\left(\mathrm{~m}^{-1}\right)$ \\
\hline Upper Permian (Layer 1) & $3 \times 10^{-15}$ & $10^{-6}$ \\
Upper Pennsylvanian (Layer 2) & $10^{-12}$ & $10^{-6}$ \\
Barnet Shale (Layers 3-8) & $3 \times 10^{-18}$ & $10^{-5}$ \\
Ellenburger Reservoir (Layer 9) & & $10^{-6}$ \\
Crystalline Basement (Layers 10-24) & & $10^{-7}$ \\
\hline
\end{tabular}

unit (including the Hueco Formation, Woodford, and Barnett Shales) was set at $3 \times 10^{-18} \mathrm{~m}^{2}$.

The depth of the pressure envelope propagation (here estimated using the $7 \mathrm{~m}$ head contour) into the crystalline basement is strongly controlled by crystalline basement permeability. For all scenarios, pore pressure propagation continues downward after peak injection in 1996 (Fig. 8A-C) and when seismicity began to increase in 2001 (Fig. 8D-F). The $7 \mathrm{~m}$ excess head contour extends to a depth of about $4 \mathrm{~km}$ below the base of the Ellenburger in 2001 when the crystalline basement permeability is set to $10^{-16} \mathrm{~m}^{2}$ (Fig. 8D). When the permeability of the crystalline basement was increased to $3 \times 10^{-16} \mathrm{~m}^{2}$ (Fig. 8E), the $7 \mathrm{~m}$ excess head contour extends to $10 \mathrm{~km}$ below base of the Ellenburger in 2001 . When permeability is increased to $10^{-15} \mathrm{~m}^{2}$, the $7 \mathrm{~m}$ excess head contour extends to $12 \mathrm{~km}$ below the base of the Ellenburger, extending beyond the centroid of seismicity at the monitoring point located at $11 \mathrm{~km}$ depth (Fig. 8F).

Simulated injection pressure within the crystalline basement at the monitoring point at $11 \mathrm{~km}$ depth (i.e., the centroid of seismicity) for these three simulations is presented in Fig. 9. Using a bulk basement permeability of $10^{-15} \mathrm{~m}^{2}$ resulted in excess heads reaching about $7 \mathrm{~m}$ five years after peak injection. For this scenario, excess heads continued to build up to $30 \mathrm{~m}$ by 2013 (16 450 days). Using a bulk crystalline basement permeability of $3 \times 10^{-16} \mathrm{~m}^{2}$ required 17 years beyond the time of peak injection (1996) for excess heads to build up to $7 \mathrm{~m}$ at the centroid of seismicity. When the crystalline basement permeability was set at $10^{-16} \mathrm{~m}^{2}$, the results showed that excess heads of only $1.5 \mathrm{~m}$ above hydrostatic conditions by the end of the simulation in 2013.

Computed excess heads within the reservoir at the monitoring point $5 \mathrm{~km}$ to the east of the injection wells within the Ellenburger reservoir decline from about $280 \mathrm{~m}$ to $260 \mathrm{~m}$ as the crystalline basement permeability increases from $10^{-16}$ to $10^{-15} \mathrm{~m}^{2}$ (Fig. 10). This is presumably due to increased leakage of fluids into the crystalline basement. For both cases, there is little discernable lag time between peak injection in 1996 and the timing of maximum pressure within the reservoir (Fig. 10). Maximum reservoir heads (not shown, $600 \mathrm{~m}$ ) were about 100 times higher than head levels within the crystalline basement at a depth of $11 \mathrm{~km}$ (Fig. 9). Overall, peak reservoir fluid pressures decreased due to vertical leakage as crystalline basement permeability increased from $10^{-16}$ to $10^{-15} \mathrm{~m}^{2}$ in the simulations (Fig. 10).

\section{Effects of reservoir permeability variations (Scenarios 5-7)}

We next considered the effects of varying reservoir permeability (Ellenburger Group) while holding the bulk crystalline basement permeability constant $\left(10^{-15} \mathrm{~m}^{2}\right)$. As
Fig. 8. Sensitivity study showing effect of changes in crystalline basement permeability on simulated excess heads during peak injection (1996.5, left column) and the onset of seismicity (2001, right column). The reservoir permeability in all of these simulations was set at $10^{-12} \mathrm{~m}^{2}(1000 \mathrm{mD})$. Vertical exaggeration is three. The first head contour is $7 \mathrm{~m}$. Subsequent contour intervals are $29.5 \mathrm{~m}$ (i.e., $7 \mathrm{~m}, 36.5 \mathrm{~m}, 66 \mathrm{~m}, 95.5 \mathrm{~m}$, $125 \mathrm{~m}, \ldots$, etc.). Within the region of injection, the top of the Ellenburger reservoir has a depth range from about 1900 to $2700 \mathrm{~m}$ below land surface.

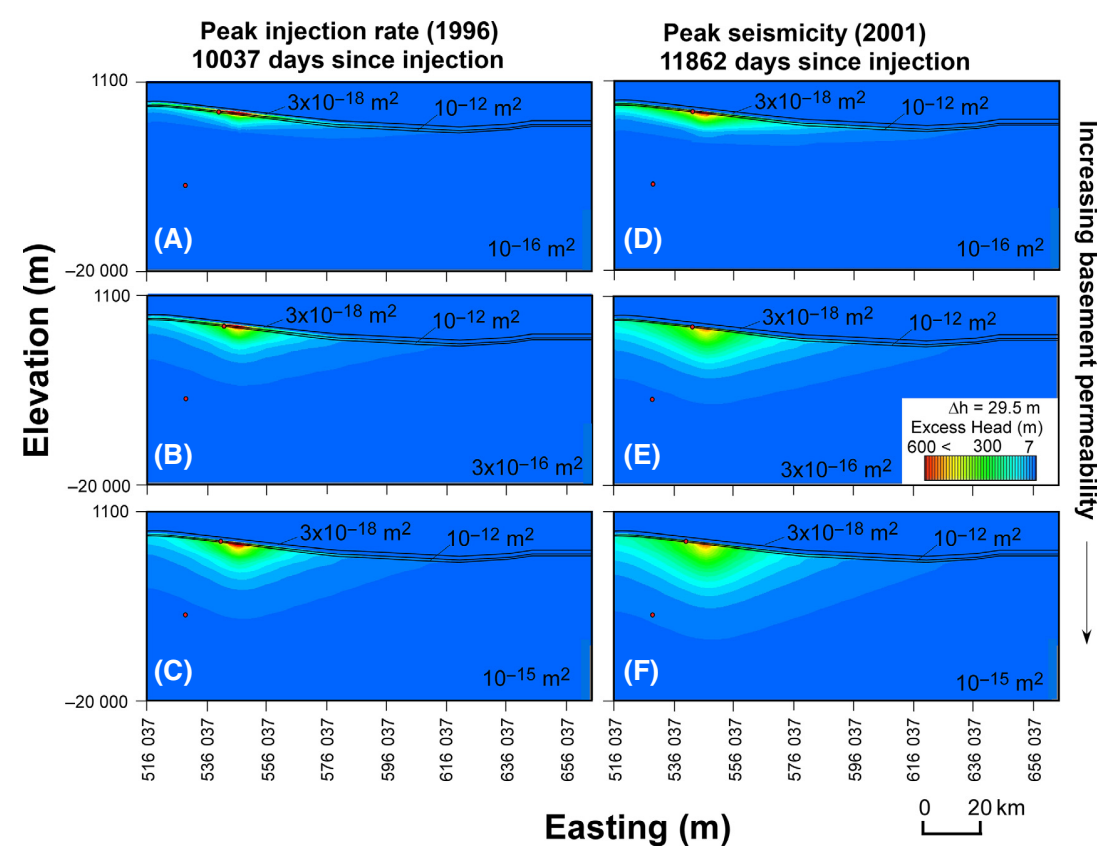




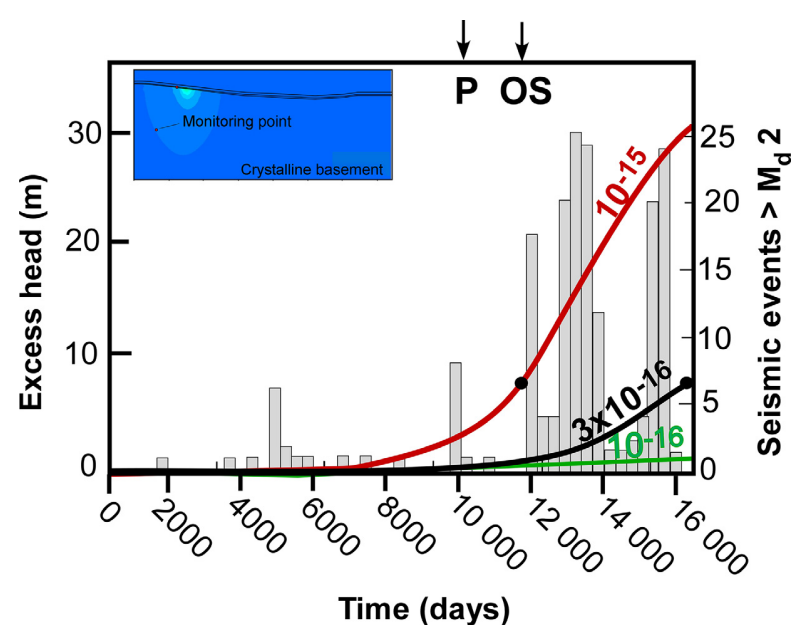

Fig. 9. Changes in excess head through time for three different crystalline basement permeability scenarios monitored at the center of seismicity within the crystalline basement $(11 \mathrm{~km}$ deep, the red point shown in the inset). Lines show simulated excess heads for the different basement permeability scenarios (red, $10^{-15} \mathrm{~m}^{2}$; black, $3 \times 10^{-16}$; green, $10^{-16} \mathrm{~m}^{2}$ ) from Fig. 8. The bar graph represents the number of earthquakes each year from 1969 to 2013 with $M_{d}>2$. The origin of the time axis is January 1 , 1969. Peak injection (P) occurred after 10037 days (1996.5). The onset of increased seismic frequency (OS) began in 2001.

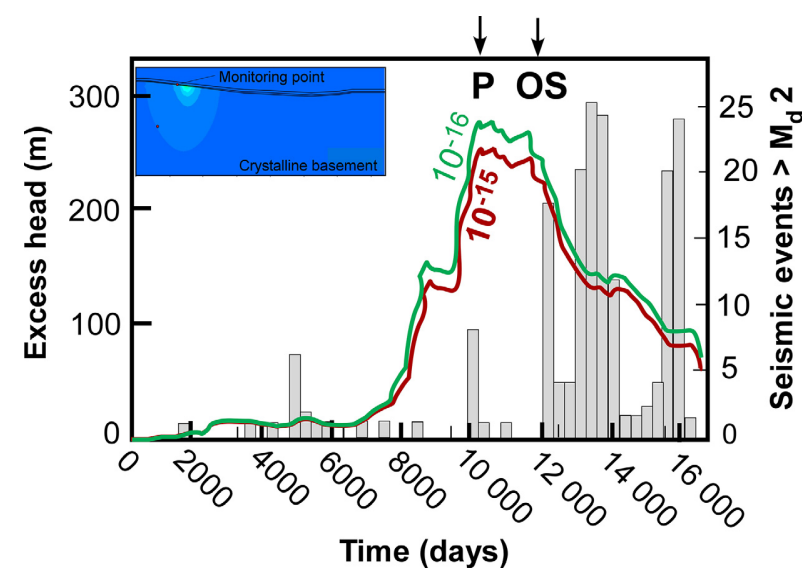

Fig. 10. Changes in excess head through time for two different crystalline basement permeability scenarios $\left(10^{-15} \mathrm{~m}^{2}\right.$ and $\left.10^{-16} \mathrm{~m}^{2}\right)$ within the Ellenburger reservoir monitoring point shown in the inset. In both simulations, the reservoir permeability was set at $10^{-12} \mathrm{~m}^{2}$. Lines show simulated excess heads for different basement permeability (red, $10^{-15} \mathrm{~m}^{2}$; green, $10^{-16} \mathrm{~m}^{2}$ ). The bar graph represents the number of earthquakes each year from 1969 to 2013 with $M_{d}>2$. The origin of the time axis is January 1 , 1969. Peak injection (P) occurred after 10037 days (1996.5). The onset of increased seismic frequency (OS) began in 2001.

noted above, core permeability measurements for the Ellenburger vary between about $10^{-14}$ and $10^{-13} \mathrm{~m}^{2}$. A basinscale effective permeability would likely be higher than $10^{-13} \mathrm{~m}^{2}$ given the multiple episodes of karstification and diagenesis that this formation experienced. When high reservoir permeability was assigned in our model for the
Ellenburger $\left(10^{-12} \mathrm{~m}^{2}\right)$, there is a significant overlap in pressure envelopes between individual injection centers as well as a maximum head of about $600 \mathrm{~m}$ (Fig. 11A,D). As reservoir permeability decreased to $10^{-14} \mathrm{~m}^{2}$, simulated reservoir heads exceeded $2000 \mathrm{~m}$ at the injection well centers. This would have exceeded the permitted injection pressures for many of the wells within the Dagger Draw oil field $(1520 \mathrm{~m}$ to $1670 \mathrm{~m})$. As the contrast between reservoir and crystalline basement permeability decreases, lateral pressure propagation within the reservoir decreases and the pressure envelope becomes much more spherical in shape (compare Fig. 12A-C). Reduction in reservoir permeability had surprisingly little effect on the magnitude of the pressures within the crystalline basement as well as the timing of the head increase associate with earthquake triggering (Fig. 13).

\section{Effects of conductive faults and permeability decay with depth (Scenarios 8-10)}

Treating permeability as a constant to a depth of $20 \mathrm{~km}$ seems a bit contrived for Precambrian crystalline rocks. As noted above, we assume that crystalline basement permeability can be represented as a bulk continuum property. Although questioned by some (e.g., Ranjram et al. 2015), numerous studies argue that permeability decreases with depth (Manning \& Ingebritsen 1999; Stober \& Bucher 2007; Ingebritsen \& Manning 2010). In two scenarios, we allowed crystalline basement permeability to decay with depth using the relationship presented by Manning and Ingebritsen (1999) and Ingebritsen \& Manning (2010):

$k=10^{-12-3.4 \log _{10}(\mathrm{~d})}$

$k=10^{-14-3.4 \log _{10}(\mathrm{~d})}$

where $k$ is permeability of the crystalline basement in $\mathrm{m}^{2}$ and $d$ is depth in $\mathrm{km}$. Equation $2 \mathrm{~b}$ is considered more applicable to stable continental crust while $2 \mathrm{a}$ is considered to be more representative of the crust in tectonically active regions. The Permian Basin in SE New Mexico is considered to be a tectonically stable region. It is unclear whether or not elevated fluid pressures associated with brine reinjection could have a similar effect on seismicity as elevated tectonic stresses.

We also considered the presence of a vertical conductive fault (between $10^{-14}$ and $10^{-15} \mathrm{~m}^{2}$ ) centered in the region of increased seismicity (Fig. 14A,B,E,F). The fault zone was surrounded by a lower-permeability crystalline basement $\left(10^{-16} \mathrm{~m}^{2}\right)$. As noted above, it is plausible that the clustering of earthquake epicenters along a north-south region may be indicative of a wide conductive fault zone.

The presence of a permeable fault zone surrounded by a lower-permeability crystalline basement matrix $\left(10^{-16} \mathrm{~m}^{2}\right)$ 
Fig. 11. Plan view map showing effects of changes in reservoir permeability on simulated excess heads during peak injection (1996.5, left column) and peak seismicity (2001, right column). The crystalline basement permeability in all of these simulations was set at $10^{-15} \mathrm{~m}^{2}(1 \mathrm{mD})$. The yellow squares denote the injection well locations. The red circle denotes the monitoring point in the reservoir. The first head contour is $7 \mathrm{~m}$. Subsequent contour intervals are $29.5 \mathrm{~m}$ (i.e., $7 \mathrm{~m}, 36.5 \mathrm{~m}, 66 \mathrm{~m}$, $95.5 \mathrm{~m}, 125 \mathrm{~m}, \ldots)$.

Fig. 12. Sensitivity study showing effect of changes in reservoir permeability on computed excess heads during peak injection (1996.5, left column) and peak seismicity (2001, right column). The reservoir permeability in all of these simulations was set at $10^{-12} \mathrm{~m}^{2}$ (1000 mD). Vertical exaggeration is three. The first head contour is $7 \mathrm{~m}$. Subsequent contour intervals are $29.5 \mathrm{~m}$ (i.e., $7 \mathrm{~m}, 36.5 \mathrm{~m}, 66 \mathrm{~m}$, $95.5 \mathrm{~m}, 125 \mathrm{~m}, \ldots)$. Within the region of injection, the top of the Ellenburger reservoir has a depth range from about 1900 to $2700 \mathrm{~m}$ below land surface.
Peak injection rate (1996) 10037 days since injection

(A)

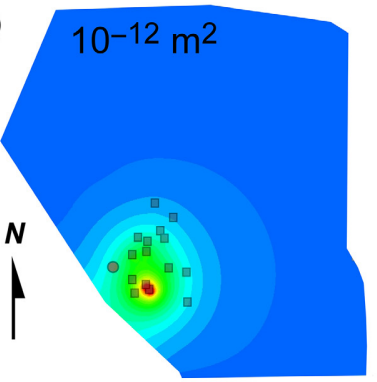

(B)
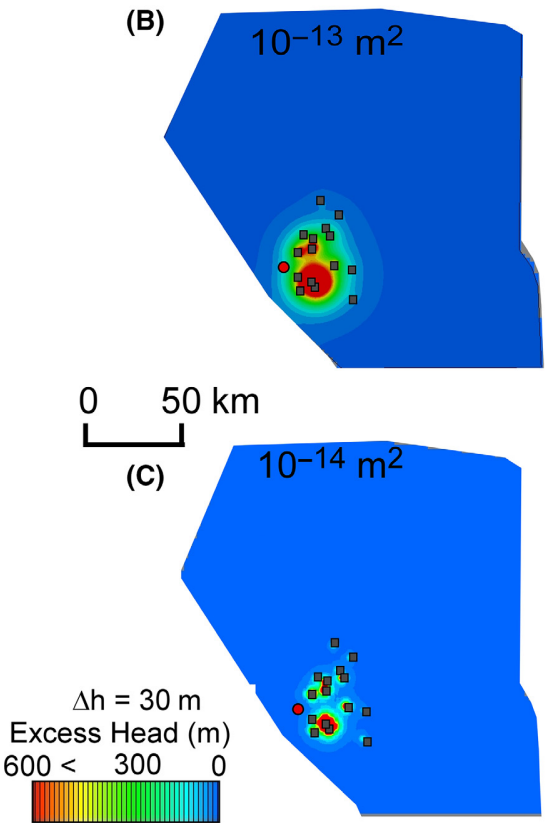

(E)

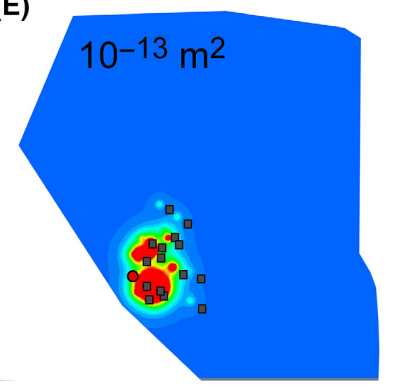

(F)

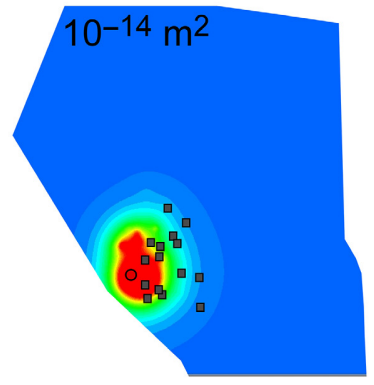

Peak seismicity (2010) 14965 days since injection
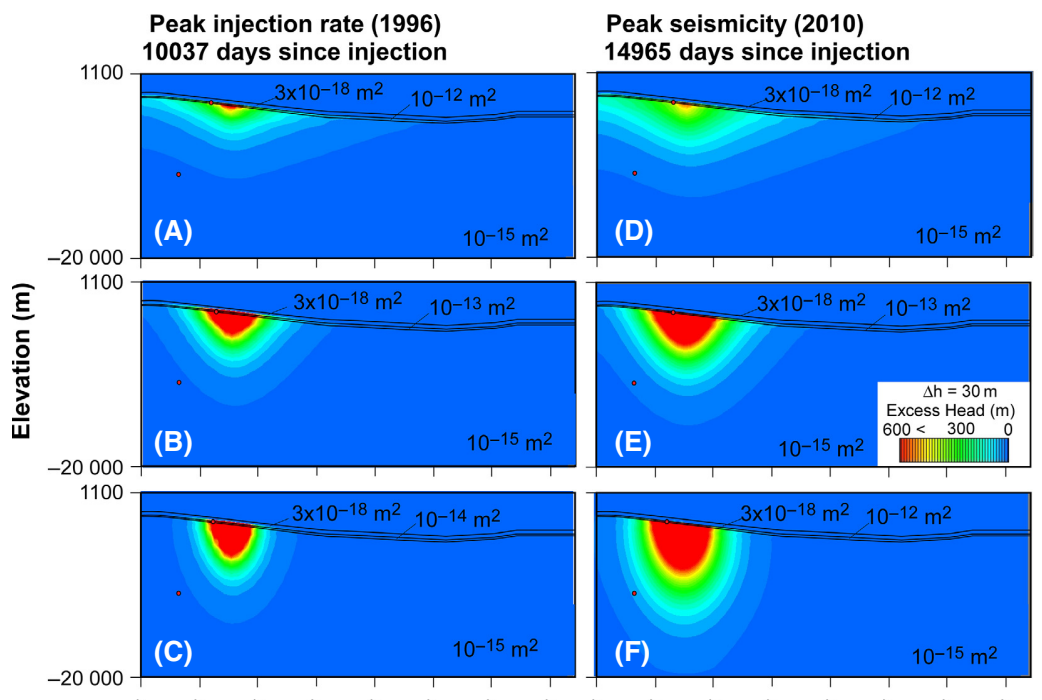

Peak seismicity (2001)

(D)

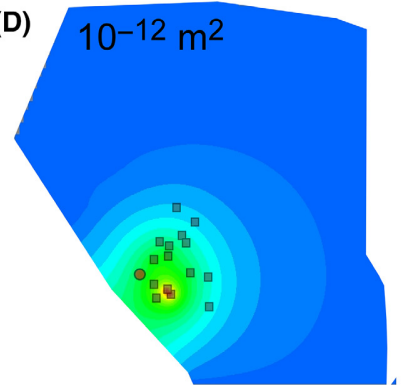

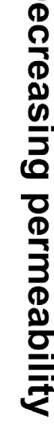

C 2016 John Wiley \& Sons Ltd, Geofluids, 16, 971-987 


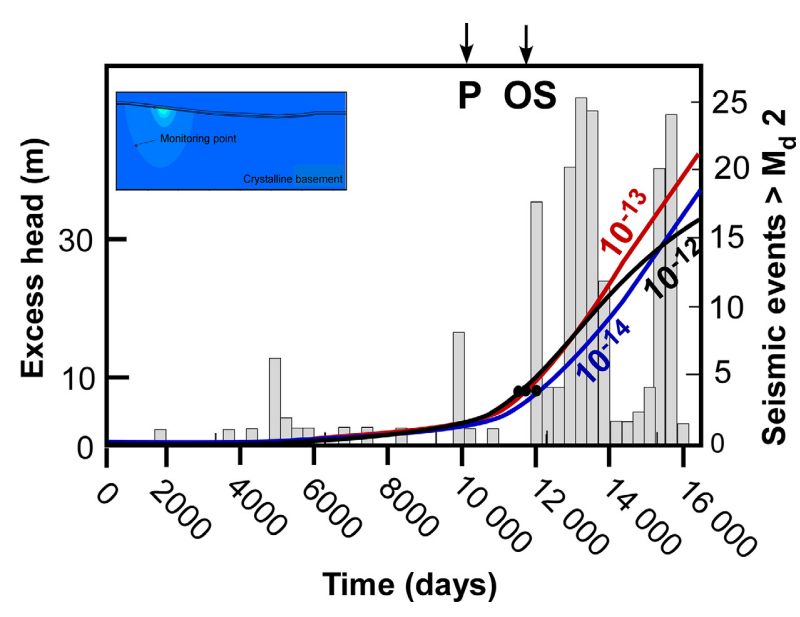

Fig. 13. Effects of changes in reservoir permeability on changes in excess head through time at the crystalline basement monitoring point shown in the inset. Lines show simulated excess heads for different reservoir permeability (black, $10^{-12} \mathrm{~m}^{2}$; red, $10^{-13} \mathrm{~m}^{2}$; blue, $10^{-14} \mathrm{~m}^{2}$ ). The bar graph represents the number of earthquakes each year from 1969 to 2013 with $M_{d}>2$. The origin of the time axis is January 1, 1969. Peak injection (P) occurred after 10037 days (1996.5). The onset of increased seismic frequency (OS) began in 2001.

facilitated the propagation of elevated pore pressures downward along the fault to the base of the model domain. The pressure anomaly extended outwards perpendicular to the fault zone (Fig. 14A,B,E,F). The depth of propagation of the pressure front in the fault zone is sensitive to fault permeability (compare Fig. 14A,B). Using a fault permeability of $10^{-14} \mathrm{~m}^{2}$ allowed the pressure front to propagate downward to a depth of $11 \mathrm{~km}$ relatively quickly. For this scenario, excess heads exceeded the $7 \mathrm{~m}$ threshold even before peak injection occurred (Fig. 15). Had we used a critical head threshold of $50 \mathrm{~m}$, this scenario would have produced a 5 -year lag between peak injection and seismicity. Using a fault permeability, one order of magnitude lower $\left(10^{-15} \mathrm{~m}^{2}\right)$ resulted in modest head increase of less than $1 \mathrm{~m}$ during the simulation period (Fig. 15). We also ran one additional scenario setting the fault permeability equal to $3 \times 10^{-15} \mathrm{~m}^{2}$. This intermediate fault permeability scenario was able to reproduce both the 5-year lag and the $7 \mathrm{MPa}$ pressure increase.

Next, we explored two scenarios of permeability decreasing with depth. In the first scenario, the permeability decayed from $10^{-12.8}$ to $10^{-17.3} \mathrm{~m}^{2}$ (Fig. 14C,G). This scenario is consistent with crustal rocks in tectonically active regions (Ingebritsen \& Manning 2010), and we refer to this as the Ingebritsen-Manning (Ing-Man) scenario. In a second scenario, more consistent with a stable continental crust (Manning \& Ingebritsen 1999), the permeability was varied from $10^{-14.8}$ to $10^{-19.3} \mathrm{~m}^{2}$ (Fig. 14D,H). We refer to this as the Manning-Ingebritsen scenario (Man-Ing). The Ingebritsen-Manning scenario (dynamic crust) permitted the propagation of pore

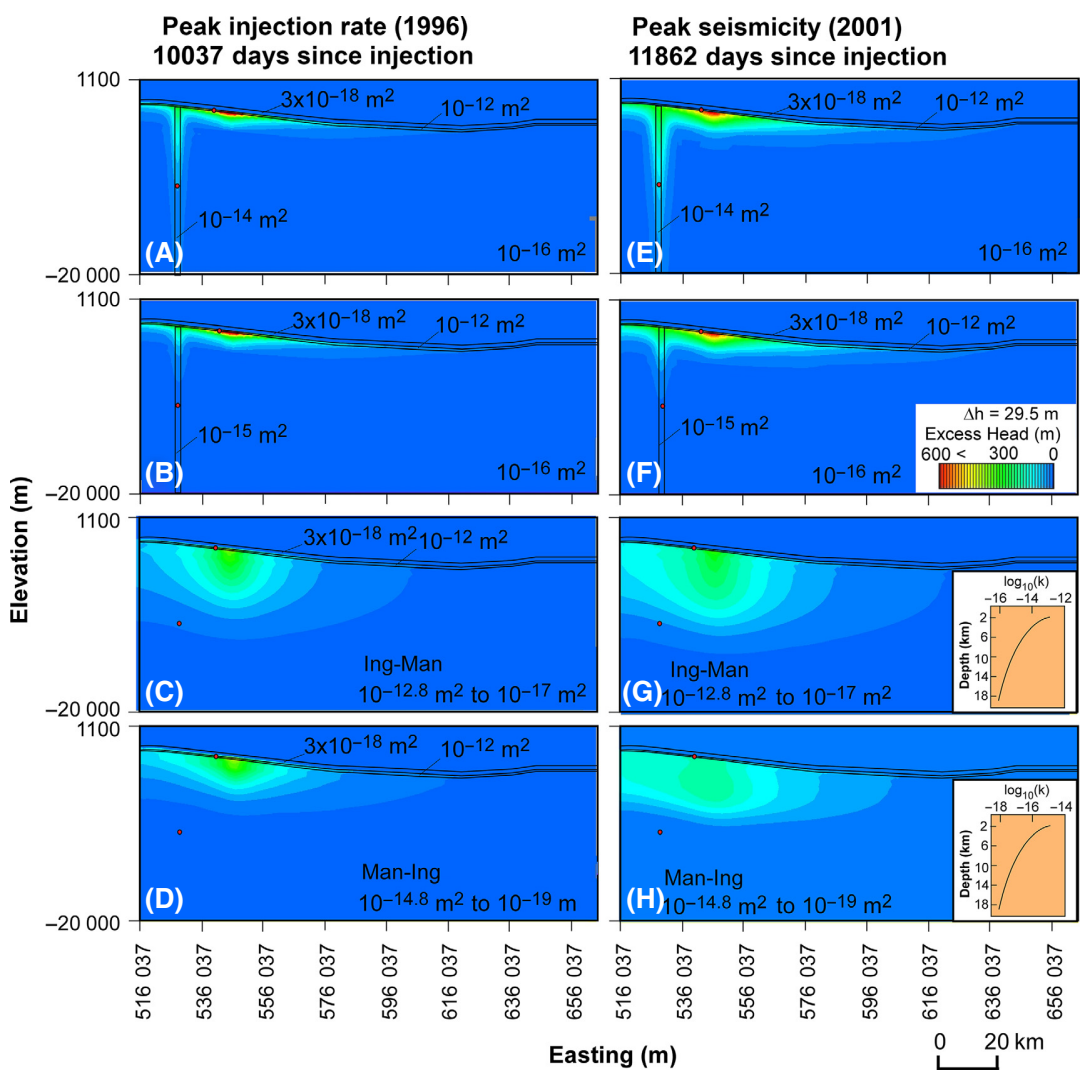

Fig. 14. Sensitivity study showing effect of changes in crystalline basement permeability on computed excess heads during peak injection (left column) and peak seismicity (right column). The reservoir permeability in all of these simulations was set at $10^{-12} \mathrm{~m}^{2}$ $(1000 \mathrm{mD})$. The following scenarios are considered here: a high-permeability $\left(10^{-14} \mathrm{~m}^{2}\right) \quad$ crystalline basement fault, Figures A \& E; a low-permeability $\left(10^{-15} \mathrm{~m}^{2}\right)$ crystalline basement fault, B \& F; Ingebritsen \& Manning (2010) permeability decay with depth imposed within the crystalline basement, C \& G; Manning \& Ingebritsen (1999) permeability decay with depth imposed within the crystalline basement, D \& $H$. Vertical exaggeration is three. The first head contour is $7 \mathrm{~m}$. Subsequent contour intervals are $29.5 \mathrm{~m}$ (i.e., $7 \mathrm{~m}, 36.5 \mathrm{~m}, 66 \mathrm{~m}$, $95.5 \mathrm{~m}, 125 \mathrm{~m}, \ldots)$. 


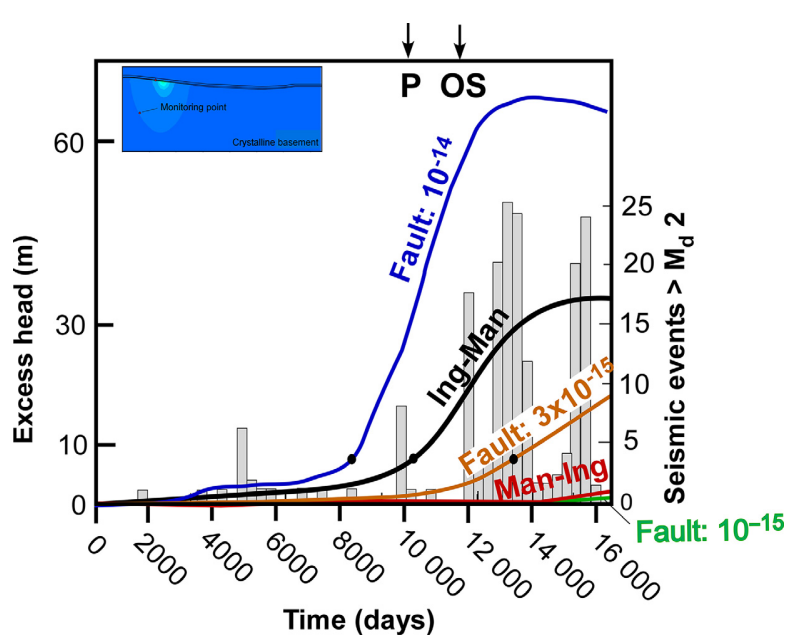

Fig. 15. Changes in excess head through time at crystalline basement monitoring point shown in inset. Lines show simulated excess heads for different basement permeability scenarios including the presence of a highpermeability $\left(10^{-14} \mathrm{~m}^{2}\right)$ fault zone (blue), permeability decay with depth using the relationship presented by Ingebritsen \& Manning (2010) (black), the presence of a relatively low-permeability $\left(3 \times 10^{-15} \mathrm{~m}^{2}\right)$ fault zone (orange), permeability decay with depth using the relationship presented by Manning \& Ingebritsen (1999) (red) and the presence of a low-permeability $\left(10^{-15} \mathrm{~m}^{2}\right)$ fault zone (green). The bar graph represents the number of earthquakes each year from 1969 to 2013 with $M_{d}>2$. The origin of the time axis is January 1, 1969. Peak injection (P) occurred after 10037 days (1996.5). The onset of increased seismic frequency (OS) began in 2001.

pressures in excess of $7-\mathrm{m}$ downward to the centroid of seismicity by 2001 (Fig. 14G). This was not the case for the Manning-Ingebritsen (stable crust) scenario (Fig. 14H). However, neither the Manning-Ingebritsen (Man-Ing, Fig. 15) nor the Ingebritsen-Manning (IngMan, Fig. 15) crystalline basement permeability scenarios predicted head increases of $7 \mathrm{~m} 5$ years after peak injection at the centroid of seismicity (Fig. 15). It is likely that some intermediate permeability-depth decay relationship in between those presented in Fig. 14 would result in a head change of $7 \mathrm{~m}, 5$ years after peak injection at the centroid of seismicity.

\section{Pressure management scenarios (Scenarios 11-13)}

Oil-field brine reinjection wells are typically repurposed from exploration boreholes or wells from mature oil fields that are no longer productive. Their proximity to active production wells is one of the key factors in deciding which wells are used for reinjection of oil-field brines. Transportation expenses required for trucking or piping produced fluids from an active production well to the reinjection well is one of the main costs of reinjection. As noted above, the volumetric fluid injection rate is clearly an important factor in triggering seismicity (Keranen et al. 2014; Walsh \& Zoback 2015; Weingarten et al. 2015).
Within the carbon capture and subsurface storage community, it has been proposed that basin-scale injection of $\mathrm{CO}_{2}$ will lead to elevated pore pressures (Person et al. 2010) and this could result in induced seismicity (Zoback \& Gorelick 2012). Management strategies have recently been proposed to reduce high pressures in reservoirs where supercritical $\mathrm{CO}_{2}$ is being injected in order to prevent hydraulic fracturing and vertical (upward) leakage of saline fluids (Buscheck et al. 2012).

Here, we consider the potential benefits of redistribution and reduction of injection rates to minimize downward fluid propagation and the buildup of fluid pressures within the underlying crystalline basement. In all of these scenarios, the permeability of the crystalline basement was set at $10^{-15} \mathrm{~m}^{2}$ and the Ellenburger reservoir permeability was set at $10^{-12} \mathrm{~m}^{2}$. The 'base case' (Base), which is used for comparison purposes, is identical to the earlier scenario presented in Fig. 11A,D (reproduced here in Fig. 16A,D). We ran four simulations considering three different injection and redistribution strategies.

In the first two cases, we redistributed the volume of fluid injected at the 15 reinjection wells. The total volume of fluids injected per time step into the Dagger Draw oil field was the same as in all base case. In the first management scenario considered (Fig. 16B,E), all of the 15 injection well centers used the same average injection rate ('Ave') per time step. In this scenario, peak injection still occurs in 1996, but the injection rates are evenly distributed across all the wells at any given time step. Relative to the base case, this resulted in injection rates decreasing in some wells and increasing in others. The computed reservoir head distribution does not change dramatically from the base case ('Obs', Fig. 17), but the maximum head changes quite significantly (i.e., contours above $400 \mathrm{~m}$ are absent in Fig. 16B,E). Within the crystalline basement, heads are only reduced by several meters due to this redistribution in injection rates (Fig. 17). Next we weighted the injection rates such that wells closest to the southwestern boundary fault (i.e., the no-flow boundary) received about half as much oil-field brine as wells furthest away (to the northeast). This was done by creating weights for each well's pumping rates and injection rates that vary linearly with distance from the southwest boundary. As with the 'Ave' scenario, the total amount of fluids injected remained the same as in the base case. The computed excess head increase at the centroid of seismicity is only two meters less than the 'Ave' scenario (Wgt, Fig. 16C,F; Wgt line, Fig. 17). This was somewhat surprising. Reducing injection rates by $50 \%$ and $90 \%$ had the most dramatic decrease in simulated fluid pressure at the crystalline basement monitoring point (lines 50\% and 90\%, Fig. 17). These results argue that it is not how you inject but how much you inject that plays the most important role in pressure management. These results indicate that managing 


\section{Peak injection rate (1996) 10037 days since injection}

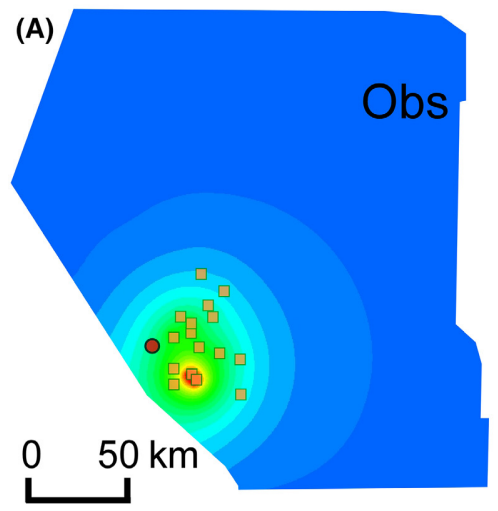

(B)

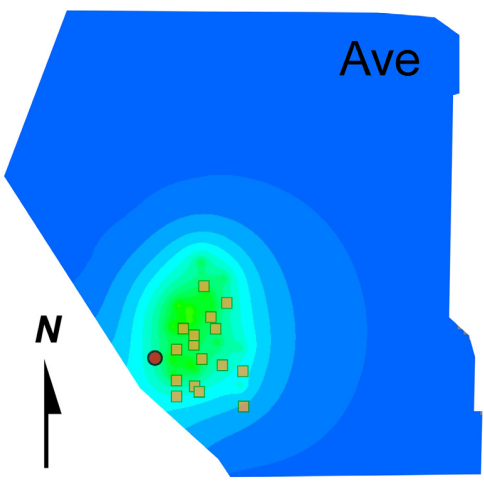

(C)

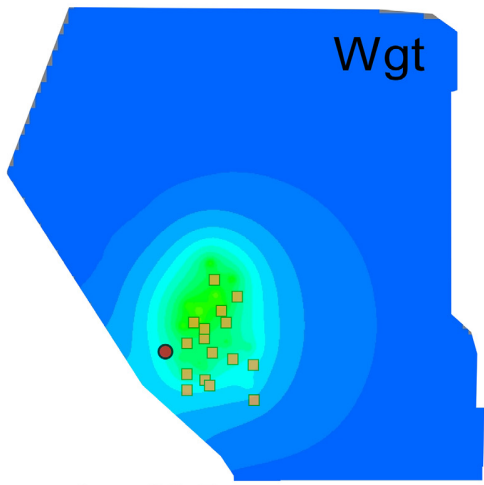

$\Delta \mathrm{h}=29.5 \mathrm{~m}$

Excess head $(\mathrm{m})$

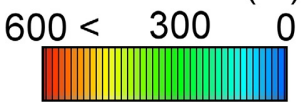

\section{Peak seismicity (2001) 11862 days since injection}

(D)

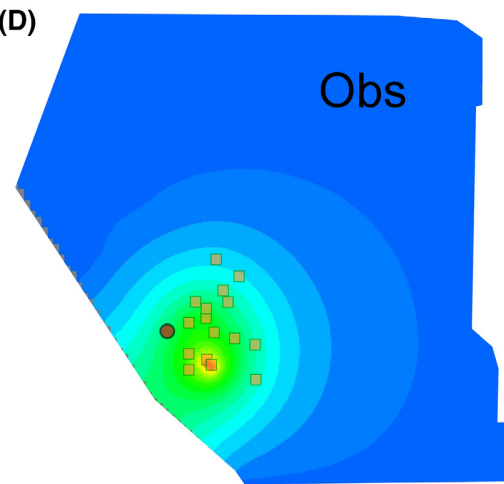

(E)

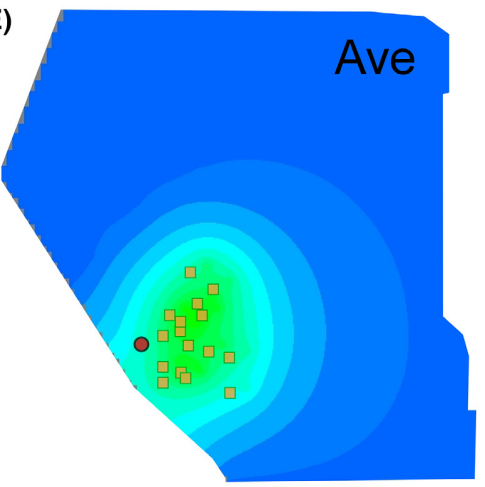

(F)

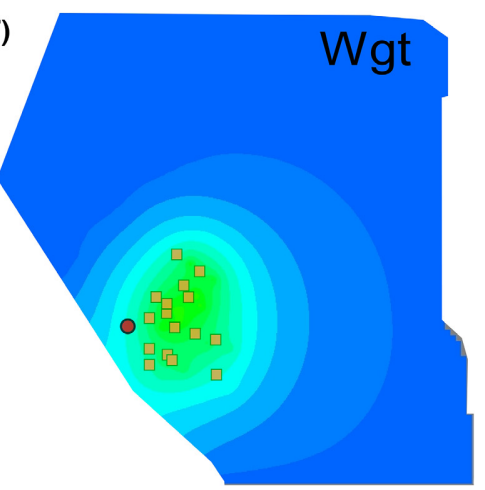

Fig. 16. Plan view map showing effects of changes in reservoir injection rates strategies on computed excess heads during peak injection (left column) and peak seismicity (right column). The crystalline basement permeability in all of these simulations was set at $10^{-15} \mathrm{~m}^{2}(1 \mathrm{mD})$, and the reservoir permeability was $10^{-12} \mathrm{~m}^{2}(1000 \mathrm{mD})$. The yellow squares denote the injection well locations. The red circle denotes the monitoring point in the reservoir. The injection scenarios considered include the observed (Obs, A \& D), average (Ave, B \& E), and weighted by distance from the southwest noflow boundary assumed to represent a fault zone (Wgt, C \& F). The first head contour is $7 \mathrm{~m}$. Subsequent contour intervals are $29.5 \mathrm{~m}$ (i.e., 7 m, 36.5 m, 66 m, 95.5 m, 125 m, ... etc.). The top of the Ellenburger reservoir has a depth range from about 2430 to $5250 \mathrm{~m}$ below land surface.

rates and volumes of injectate are critical to reducing the potential of induced seismicity.

\section{DISCUSSION}

How do our estimates of crystalline basement permeability reported here compare to the other modeling studies that have tried to estimate fluid pressures within the crystalline basement? Figure 2 presents crystalline basement hydraulic diffusivity versus depth comparing our results (gray boxes) to those from Hsieh \& Bredehoeft (1981) and Keranen et al. (2014). We also included crystalline basement hydraulic diffusivity estimates from studies that investigated triggered seismicity not related to saline water reinjection including Saar \& Manga (2003) and Ge et al. (2009). We used hydraulic diffusivity rather than permeability because 


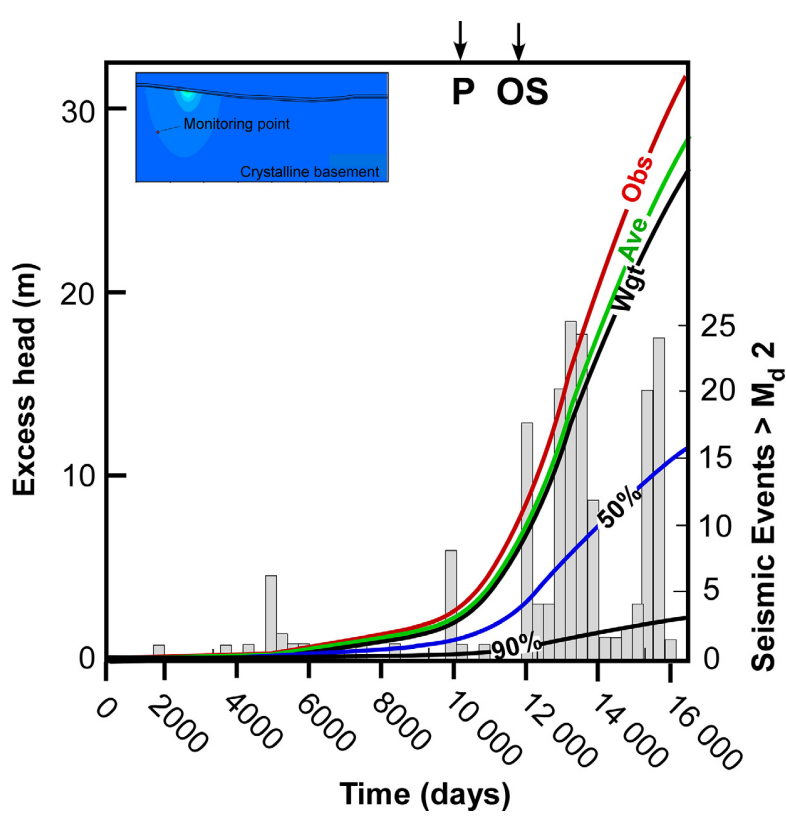

Fig. 17. Computed changes in excess head through time in response to different injection strategies evaluated at crystalline basement monitoring point shown in inset. Lines show simulated excess heads for different injection scenarios including the observed injection rates (Obs), the average injection rates (Ave), weighted injection rates (Wgt) with higher weights given to wells located furthest from the (southwest) no-flow boundary, a fifty percent reduction in the observed injection rates (50\%), a $90 \%$ reduction in the observed injection rates $(90 \%)$. In all model runs, the permeability of the crystalline basement was $10^{-15} \mathrm{~m}^{2}$ and the one of the Ellenberger reservoir was $10^{-12} \mathrm{~m}^{2}$. The bar graph represents the number of earthquakes each year from 1969 to 2013 with $M_{d}>2$. The origin of the time axis is January 1, 1969. Peak injection (P) occurred after 10037 days (1996.5). The onset of increased seismic frequency (OS) began in 2001.

pressure diffusion rates are controlled by both permeability and rock/fluid compressibility (and hence, specific storage). The hydraulic diffusivities $\left(K / S_{s}\right)$ reported in this study for the bulk crystalline basement and for a conductive fault zone are about 1-2 orders of magnitude lower than those reported by prior studies of triggered seismicity associated with brine reinjection. They are in the same range as those reported by Saar \& Manga (2003) and Ge et al. (2009). This seems plausible since the centroid of seismicity is $15 \mathrm{~km}$ to the west of the Dagger Draw oil field and is deeper than the triggered seismicity reported at these other sites (Table 1).

Only two scenarios presented above produced elevated pore pressures above $7 \mathrm{~m}$ five years after peak injection. None of the scenarios presented resulted in a head increase greater than $65 \mathrm{~m}$ five years after peak injection in 2001 . If we had relaxed the $7 \mathrm{~m}$ metric for triggered seismicity and assumed an elevated head increase between 1 and $60 \mathrm{~m}$ could trigger seismicity, then several additional permeability scenarios would have satisfied the 5-year lag time criteria. Using this approach, we find a range of permeability scenarios that could satisfy our criteria. These included a permeability range between $10^{-15}$ and $10^{-16} \mathrm{~m}^{2}$ assuming a homogeneous crust and $10^{-14}$ and $10^{-15} \mathrm{~m}^{2}$ for a conductive vertical fault along which pressure could migrate downward. Allowing permeability to decay with depth between $10^{-12.8}$ and $10^{-17} \mathrm{~m}^{2}$ (Ing-Man, Fig. 15) would also have produced excess head of about $15 \mathrm{~m}$ at $11 \mathrm{~km}$ depth, 5 years after peak injection.

How accurate are the estimates of maximum excess heads reported here? As noted in the methods section, we used a relatively coarse grid $(\Delta x=2.1 \mathrm{~km}, \Delta \mathrm{y}=2.3 \mathrm{~km})$ in this study. Actual wellhead pressures could be $20 \%$ higher than what is reported if a more refined grid was used $(\Delta x=\Delta y=0.7 \mathrm{~km})$. It has also been known for some time that numerical models systematically under predict wellhead pressures. We can obtain a better estimate of actual wellhead pressure using a Peaceman correction (Peacman 1983):

$\Delta h_{\mathrm{well}}=\Delta h_{\mathrm{cell}}+\frac{Q}{2 \pi T} \operatorname{In}\left(\frac{0.2 \Delta x}{r}\right)$

where $\Delta h_{\text {well }}$ is the estimated drawdown (positive) at the well, $\Delta h_{\text {cell }}$ is the computed drawdown (initial - current head; positive) at the cell, $r$ is the distance from the well to the cell, and $\Delta x$ is the cell dimension.

If we consider the worst case scenario and assume that the injection well very close to the finite difference node (here we assume $14 \mathrm{~cm}$ ), and use the conditions described in the above base scenario for the Ellenburger group (permeability $=10^{-12} \mathrm{~m}^{2}, S_{s}=10^{-6} \mathrm{~m}^{-1}$ ), with a maximum pumping rate of $10^{6}$ barrels/month $\left(52300 \mathrm{~m}^{3}\right.$ day $\left.^{-1}\right)$, this would result in a maximum wellhead increase of $98 \mathrm{~m}$ above the computed nodal head. As the maximum nodal head for the base case scenario is about $600 \mathrm{~m}$, the maximum wellhead increase for the base case scenario would be about $700 \mathrm{~m}$ which is still below the permitted wellhead pressures for the Dagger Draw oil field (1520-1670 m).

This is not the first study to propose that a lag may exist between injection and seismicity-a similar lag between increases in injection and the onset of seismic activity was observed near Jones and Prague, Oklahoma (Walsh \& Zoback 2015). Ge et al. (2009) reported that there was a 2.7 year lag between the filling of the Zipingpu Reservoir and the Wenchuan earthquake $\left(M_{w}=7.9\right)$ which occurred at an estimated depth of between 10 and $20 \mathrm{~km}$. If the Dagger Draw seismicity is in fact induced by the injection of the oilfield wastewater, then it represents the deepest example of triggered earthquakes associated with brine reinjection into basal sedimentary reservoirs to date.

Trying to reduce pore pressure buildup by optimizing reinjection rates, either by injecting at the same volume of fluid at each well or decreasing the injection rates in wells closest to a no-flow boundary, was found to have a second-order effect on simulated fluid pressure increases at the crystalline basement monitoring point. More dramatic 
pressure maintenance scenarios involving significant reduction (by $50 \%$ ) in the volume of injected fluids would need to be considered. Reduction in the volumes of reinjected fluids through desalination of oil-field brines represents an attractive management option in the water-scarce Southwestern USA (Balch \& Muraleedharan 2014). Balch \& Muraleedharan (2014) pilot desalination study estimated that the cost of disposal of produced oilfield brines dropped from as high as $\$ 2.5 /$ barrel to $\$ 0.31 /$ barrel.

\section{CONCLUSIONS}

Hydrologic modeling was used to in this study to test the hypothesis that increased rates of seismicity at $11 \mathrm{~km}$ depth within the crystalline basement $15 \mathrm{~km}$ west of the Dagger Draw oil field is the result of saline water injection into the basal Ellenburger reservoir. We considered several scenarios including assigning an effective or bulk permeability value to the crystalline basement, including a conductive fault zone surrounded by tighter crystalline basement rocks, and allowing permeability to decay with depth. We found that the observed lag time between peak injection in 1996 and the onset of increase seismicity in 2001 can be explained by the time required for the pressure front to migrate through the crystalline basement. We assumed a $7 \mathrm{~m}$ head increase as a threshold for induced seismicity. The 5-year lag time helps constrain the permeability of the crystalline basement. If the crystalline basement was assigned a bulk permeability higher than $10^{-15} \mathrm{~m}^{2}$, then delay between peak injection and seismicity would have been shorter than 5 years. Choosing a bulk permeability less than $10^{-16} \mathrm{~m}^{2}$ would not permit pressures to build sufficiently to induce seismicity. If a permeable fault zone is present, its permeability needs to be about $3 \times 10^{-15} \mathrm{~m}^{2}$. We also tested several different pressure management scenarios varying the injection rates in wells as well as reducing the total volume of fluid injected. Pressure management scenarios that reduced computed excess heads by over $50 \%$ within the crystalline basement resulted from reducing the total volume of reinjected fluids by a factor of 2 or more. Redistributing the volume of injected fluid between individual wells did not have a significant impact on fluid pressures within the crystalline basement.

\section{ACKNOWLEDGEMENTS}

This work was supported, in part, by a US Geological Survey Seismic Hazards Program (NEHRP) grant to Jim Evans, Peter Mozley, and Mark Person. Support from the NSF Epscor grant entitled, 'Energize New Mexico' to Mark Person, and a Geological Society of America Laubach Award to Peter Mozley are also acknowledged. The review comments of Paul Hsieh and an anonymous reviewer are gratefully acknowledged.

\section{REFERENCES}

Annual Report of the New Mexico Oil and Gas Engineering Commission Inc., 1969-2003, Volume V I-A, southeastern New Mexico.

Balch RS, Muraleedharan S (2014) Cost-Efficient Well-Head Purification of Produced Water using a HumidificationDehumidification Process. In SPE Western North American and Rocky Mountain Joint Meeting. Society of Petroleum Engineers.

Barton CA, Zoback MD, Moos D (1995) Fluid flow along potentially active faults in crystalline rock. Geology, 23, 683-6.

Bogdanov II, Mourzenko VV, Thovert JF, Adler PM (2003) Effective permeability of fractured porous media in steady state flow. Water Resources Research, 39, 1023.

Brace WF (1984) Permeability of crystalline rocks: new in situ measurements. Journal of Geophysical Research: Solid Earth, 89, 4327-30.

Broadhead RF (1999) Underdeveloped oil fields - Upper Pennsylvanian and Lower Wolfcampian carbonate reservoirs of southeast New Mexico. Carbonates and Evaporites, 14, 84-105.

Buscheck TA, Sun Y, Chen M, Hao Y, Wolery TJ, Bourcier WL, Court B, Celia MA, Friedmann SJ, Aines RD (2012) Active CO 2 reservoir management for carbon storage: analysis of operational strategies to relieve pressure buildup and improve injectivity. International Journal of Greenhouse Gas Control, 6, $230-45$.

Caine JS, Tomusiak SR (2003) Brittle structures and their role in controlling porosity and permeability in a complex Precambrian crystalline-rock aquifer system in the Colorado Rocky Mountain Front Range. Geological Society of America Bulletin, 115, 1410 24.

Clauser C (1992) Permeability of crystalline rocks. Eos, Transactions American Geophysical Union, 73, 233-8.

Cox DM, Brinton L, Tinker SW (1998) Depositional facies and porosity development of an upper Pennsylvanian algal mound reservoir, south Dagger Draw, Eddy County, New Mexico. In: Winfree, KE (ed.) Cored Reservoir Examples from Upper Pennsylvanian and Lower Permian Carbonate Margins, Slopes and Basinal Sandstones, West Texas Geological Society, West Texas Geological Society, Midland, TX.

Edel S, (2015) Characterizing suspected induced seismicity in SE New Mexico in the vicinity of the Waste Isolation Pilot Plant, NM Tech MSc Thesis, $91 \mathrm{p}$.

Edel S, Bilek S, Broadhead R (2016) Earthquake Relocation in SE New Mexico, USA: Possible Induced Seismicity in the Area of the Waste Isolation Pilot Plant (WIPP) Site, Bulletin of the Seismological Society of America (in revision).

Forster C, Smith L (1989) The influence of groundwater flow on thermal regimes in mountainous terrain: a model study. Journal of Geophysical Research, 94, 9439-51.

Ge S, Liu M, Lu N, Godt J, Luo G (2009) Did the Zipingpu Reservoir trigger the 2008 Wenchuan earthquake? Geophysical Research Letters, 36, 20.

Harbaugh AW, McDonald MG (1996) User's Documentation for MODFLOW-96, an Update to the US Geological Survey Modular Finite-Difference Ground-Water Flow Model. No. 96485. US Geological Survey; Branch of Information Services [distributor].

Horton S (2012) Disposal of hydrofracking waste fluid by injection into subsurface aquifers triggers earthquake swarm in central Arkansas with potential for damaging earthquake. Seismological Research Letters, 83, 250-60.

Hsieh PA, Bredehoeft JD (1981) A reservoir analysis of the Denver earthquakes: a case of induced seismicity. Journal of Geophysical Research, 86, 903. 
Ingebritsen SE, Gleeson T (2015) Crustal permeability: introduction to the special issue. Geofluids, 15, 1-10.

Ingebritsen SE, Manning CE (2010) Permeability of the continental crust: dynamic variations inferred from seismicity and metamorphism. Geofluids, 10, 193-205.

Keranen KM, Savage HM, Abers GA, Cochran ES (2013) Potentially induced earthquakes in Oklahoma, USA: links between wastewater injection and the $2011 \mathrm{M}_{\mathrm{w}} 5.7$ earthquake sequence. Geology, 41, 699-702.

Keranen KM, Weingarten M, Abers GA, Bekins BA, Ge S (2014) Induced earthquakes. Sharp increase in central Oklahoma seismicity since 2008 induced by massive wastewater injection. Science, 345, 448-51.

Kim W (2012) Induced Seismicity Associated with Waste Fluid Injection into Deep Wells in Youngstown, Ohio. In AGU Fall Meeting Abstracts Volume 1, p. 2496.

Kim WY (2013) Induced seismicity associated with fluid injection into a deep well in Youngstown, Ohio. Journal of Geophysical Research: Solid Earth, 118, 3506-18.

Klimczak C, Schultz RA, Parashar R, Reeves DM (2010) Cubic law with aperture-length correlation: implications for network scale fluid flow. Hydrogeology Journal, 18, 851-62.

Konikow LF, Bredehoeft JD (1992) Ground-water models cannot be validated. Advances in water resources, $15,75-83$.

Loucks RG (2003) Review of the Lower Ordovician Ellenburger Group of the Permian Basin. West Texas, Bureau of Economic Geology, University of Texas, Austin, TX. 95 p.

Lowell R, Van Cappellen P, Germanovich LN (1993) Silica precipitation in fractures and the evolution of permeability in hydrothermal upflow zones. Science, 260, 192-4.

Mailloux BJ, Person M, Kelley S, Dunbar N, Cather S, Strayer L, Hudleston P (1999) Tectonic controls on the hydrogeology of the Rio Grande Rift, New Mexico. Water Resources Research, 35, 2641-59.

Manga M, Beresnev I, Brodsky EE, Elsworth D, Ingebritsen SE, Mays DC, Wang CY (2012) Changes in permeability caused by transient stresses: field observations, experiments, and mechanisms. Reviews of Geophysics, 50, RG2004.

Manning AH, Caine JS (2007) Groundwater noble gas, age, and temperature signatures in an Alpine watershed: valuable tools in conceptual model development. Water Resources Research, 43, W04404.

Manning CE, Ingebritsen SE (1999) Permeability of the continental crust: constraints from heat flow models and metamorphic systems. Reviews in Geophysics, 37, 127-50.

Neuman SP (2005) Trends, prospects and challenges in quantifying flow and transport through fractured rocks. Hydrogeology Journal, 13, 124-47.

New Mexico Oil Conservation Division (2016) http:// ocdimage.emnrd.state.nm.us/imaging/AEOrderCriteria.aspx

Oreskes N, Shrader-Frechette K, Belitz K (1994) Verification, validation, and confirmation of numerical models in the earth sciences. Science, 263, 641-6.

Peaceman DW (1983) Interpretation of well-block pressures in numerical reservoir simulation with nonsquare grid blocks and anisotropic permeability. Society of Petroleum Engineers Journal, $23,531-43$.
Pepin J, Person M, Phillips F, Kelley S, Timmons S, Owens L, Witcher J, Gable C (2015) Deep fluid circulation within crystalline basement rocks and the role of hydrologic windows in the formation of the truth or consequences, New Mexico low-temperature geothermal system. Geofluids, 15, 139-60.

Person M, Banerjee A, Rupp J, Medina C, Lichtner P, Gable C, Pawar R, Celia M, McIntosh J, Bense V (2010) Assessment of basin-scale hydrologic impacts of $\mathrm{CO}_{2}$ sequestration, Illinois basin. International Journal of Greenhouse Gas Control, 4, 840 54.

Ranjram M, Gleeson T, Luijendijk E (2015) Is the permeability of crystalline rock in the shallow crust related to depth, lithology or tectonic setting? Geofluids, 15, 106-19.

Saar MO, Manga M (2003) Seismicity induced by seasonal groundwater recharge at Mt. Hood, Oregon. Earth and Planetary Science Letters, 214, 605-18.

Schwartz FW, Zhang H (2003) Fundamentals of Groundwater. John Wiley \& Sons, New York. 583.

Snow DT (1968) Rock fracture spacings, openings, and porosities. Journal of Soil Mechanics \& Foundations Division, 94, 73-91.

Speer SW (1993) Upper Pennsylvanian deposits. In: Atlas of Major Rocky Mountain Gas Reservoirs, pp. 154-6. New Mexico Bureau of Mines and Mineral Resources, Socorro, NM.

Stober I, Bucher K (2007) Hydraulic properties of the crystalline basement. Hydrogeology Journal, 15, 213-24.

Townend J, Zoback MD (2000) How faulting keeps the crust strong. Geology, 28, 399-402.

Walsh FR, Zoback MD (2015) Oklahoma's recent earthquakes and saltwater disposal. Science Advances, 1, el500195.

Weingarten M, Ge S, Godt JW, Bekins BA, Rubinstein JL (2015) High-rate injection is associated with the increase in U.S. midcontinent seismicity. Science, 348, 1336-40.

Wright WF (1979) Petroleum Geology of the Permian Basin: West Texas Geological Society. Publication 79-71, 98 pp.

Zhang Y, Person M, Rupp J, Ellett K, Celia MA, Gable CW, Bowen B, Evans J, Bandilla K, Mozley P, Dewers T, Elliot T (2013) Hydrogeologic controls on induced seismicity in crystalline basement rocks due to fluid injection into basal reservoirs. Ground Water, 51, 525-38.

Zoback MD, Gorelick SM (2012) Earthquake triggering and large-scale geologic storage of carbon dioxide. Proceedings of the National Academy of Sciences of the United States of America, $109,10164-8$.

\section{SUPPORTING INFORMATION}

Additional Supporting Information may be found online in the supporting information tab for this article:

Appendix S1. Effects of model discretization on simulated head increases and estimates of well head pressures. 


\title{
GEOFLUIDS
}

\author{
Volume 16, Number 5, December 2016 \\ ISSN 1468-8115
}

\section{CONTENTS}

801 Injection-induced seismicity in Carbon and Emery Counties, central Utah M.R.M. Brown and M. Liu

813 Large-scale chemical stratification of fluids in the crust: hydraulic and chemical data from the geothermal research site Urach, Germany K. Bucher and I. Stober

826 The October 2008 Nový Kostel earthquake swarm and its gas geochemical precursor F.H. Weinlich, R. Gaždová, M. Teschner and J. Poggenburg

841 Quantitative analysis of $\mathrm{COH}$ fluids synthesized at HP-HT conditions: an optimized methodology to measure volatiles in experimental capsules

C. Tiraboschi, S. Tumiati, S. Recchia, F. Miozzi and S. Poli

856 Origin of dolomites in the Cambrian (upper 3rd-Furongian) formation, south-eastern Sichuan Basin, China M.C. Hou, W.J. Jiang, F.C. Xing, S.L. Xu, X.C. Liu and C. Xiao

877 Chemical evolution of metamorphic fluids in the Central Alps, Switzerland: insight from LA-ICPMS analysis of fluid inclusions K. Rauchenstein-Martinek, T. Wagner, M. Wälle, C.A. Heinrich and T. Arlt

909 Organic-inorganic rock-fluid interactions in stylolitic micro-environments of carbonate rocks: a FIB-TEM study combined with a hydrogeochemical modelling approach H. -M. Schulz, R. Wirth and A. Schreiber

925 Linked thermal convection of the basement and basinal fluids in formation of the unconformity-related uranium deposits in the Athabasca Basin, Saskatchewan, Canada A.A. Pek and V.I. Malkovsky

941 The role of the stress regime on microseismicity induced by overpressure and cooling in geologic carbon storage V. Vilarrasa

954 Numerical model of pore-pressure diffusion associated with the initiation of the 2010-2011 Guy-Greenbrier, Arkansas earthquakes P.O. Ogwari and S.P. Horton

971 Exploring the potential linkages between oil-field brine reinjection, crystalline basement permeability, and triggered seismicity for the Dagger Draw Oil field, southeastern New Mexico, USA, using hydrologic modeling Y. Zhang, S.S. Edel, J. Pepin, M. Person, R. Broadhead, J.P. Ortiz, S.L. Bilek, P. Mozley and J.P. Evans

988 Fluid chemistry in the Solitaire and Dodo hydrothermal fields of the Central Indian Ridge

S. Kawagucci, J. Miyazaki, T. Noguchi, K. Okamura, T. Shibuya, T. Watsuii, M. Nishizawa, H. Watanabe, K. Okino, N. Takahata, Y. Sano, K. Nakamura, A. Shuto, M. Abe, Y. Takaki, T. Nunoura, M. Koonjul, M. Singh, G. Beedessee, M. Khishma, V. Bhoyroo, D. Bissessur, L.S. Kumar, D. Marie, K. Tamaki and K. Takai

1006 Direct inversion of Young's and Poisson impedances for fluid discrimination Z. Zong and $\mathrm{X}$. Yin

1017 Bleached mudstone, iron concretions, and calcite veins: a natural analogue for the effects of reducing $\mathrm{CO}_{2}$-bearing fluids on migration and mineralization of iron, sealing properties, and composition of mudstone cap rocks

X.R. Ming, L. Liu, M. Yu, H.G. Bai, L. Yu, X.L. Peng and T.H. Yang

1043 Dry $\mathrm{CO}_{2}-\mathrm{CO}$ fluid as an important potential deep Earth solvent A.G. Simakin, T.P. Salova, R.I. Gabitov and S.I. Isaenko 